\title{
CONSTITUCIÓN ECONÓMICA E INTEGRACIÓN EUROPEA
}

\author{
GONZALO MAESTRO BUELGA
}

Catedrático de Derecho Constitucional

Universidad del País Vasco 


\section{SUMARIO}

1. INTRODUCCIÓN. 2. LA CONSTITUCIÓN ECONÓMICA. 2.1. Schmitt y Neumann. 2.2. La nueva oposición entre Constitución y constitución económica. 2.3. El concepto de constitución económica. 3. LA CONSTITUCIÓN ECONÓMICA DEL ESTADO SOCIAL. 3.1. La determinación del vínculo social. 3.2. El gobierno de la economía. 4. LA GLOBALIZACIÓN ECONÓMICA, FUNDAMENTO LEGITIMADOR DE LA NUEVA CONSTITUCIÓN ECONÓMICA. 4.1. La estrategia de la globalización. 4.2. La globalización financiera. 5. EL ESTADO REGULADOR. 5.1. Estado regulador y Estado social. 5.2. Los instrumentos de regulación: las autoridades independientes. 6. LA CONSTITUCIÓN ECONÓMICA EUROPEA. 6.1. Las aproximaciones a la Constitución económica europea. 6.2. Mercado y ordenamiento de la Unión Europea. 


\title{
CONSTITUCIÓN ECONÓMICA E INTEGRACIÓN EUROPEA*
}

\author{
POR \\ GONZALO MAESTRO BUELGA \\ Catedrático de Derecho Constitucional \\ Universidad del País Vasco
}

\section{INTRODUCCIÓN}

Quizás uno de los mayores problemas con que nos encontramos a la hora de abordar la relación entre la Constitución y los procesos económicos sea el de la falta de un bagaje conceptual consolidado con el que analizar las transformaciones operadas en la regulación normativa del ámbito económico. Por eso mismo, cuando hablamos de la Constitución económica nos encontramos con que el mismo término es todo menos pacífico ${ }^{1}$. Las diferencias doctrinales no afectan sólo al alcance y contenidos otorgados a este concepto, sino a la licitud misma de su empleo ${ }^{2}$, evocando todavía el debate surgido en el origen del concepto ${ }^{3}$.

* Este trabajo se ha realizado en en marco del proyecto de investigación financiado por el Gobierno Vasco, refencia PI-1998-105, con el título "Los servicios públicos entre mercado e interés general».

1 Cocozza, F., Profili di diritto costituzionale applicato all'economia, vol. I, Giappichelli, Turín, 1995, págs. 143-7. Miccu, R., "“Economia e costituzione”, una lettura della cultura giuspubblicistica tedesca", en Quaderni del Pluralismo, 1996, n. ${ }^{\circ}$, págs. 243-288.

2 ARIÑo OrTIZ, G., Economía y Estado. Cap. III (Constitución política y modelo económico. ¿Es posible una Constitución Económica? El caso español), Pons, Madrid, 1993, págs. 95-121.

3 SCHMITT, C., I/ custode della costituzione. Milán, 1981, pág. 149. NeUMANN, F., "On the preconditions and the legal concepto of an Economic Constitution", en 
La doctrina iuspublicística mayoritaria sorteó los problemas que planteaba el constitucionalismo social y la recepción normativa de la regulación económica adoptando una concepción descriptiva de la constitución económica, operando así una suerte de neutralización de las implicaciones del concepto 4 .

Esta construcción del concepto se ha realizado ajena a la reflexión sobre la forma de Estado que se instaura en Europa desde el final de la ll Guerra Mundial. De esta forma, constitución económica es poco más que la consideración de las cláusulas constitucionales referidas a la materia económica que, en sí misma, dada la naturaleza compromisoria de la constitución del Estado social, permiten una pluralidad interpretativa, casi ilimitada, Quizás sea por eso, que el lugar más común de la doctrina sea la caracterización de las constituciones económicas de la postguerra mundial como constituciones abiertas.

Esta concepción neutralista produce efectos perversos en el análisis de las transformaciones operadas en la relación política-economia desde la década de los ochenta del pasado siglo, en la medida que permite una asimilación normativa de tos nuevos comportamientos del Estado, presentándolos como continuidad cuasi natural de unas previsiones constitucionales abierta.

En definitiva, este acercamiento permite sustraerse a là confrontación entre Estado social y Constitución económica postfordista, presentándola como mera consecuencia de la evolución del sistema, pero en absoluto contradictorias 5 .

El problema metodológico que subyace es la desvinculación de la Constitución de la forma de Estado que tiene efectos agudizados en este ámbito, campo especial de materialización de las transformaciones del Estado social.

Desde esta postura, Estado social no es sino una principio constitucional que despliega efectos jurídico-constitucionales atenuados,

Social democracy and the rule of Jaw, Kirchheimer y Neumann, Allen \& Unwin, Lon* don, 1987, págs. 44-65. pág. 144.

4 Cocozza, F., Profili di diritto costituzionale applicato all'economia, op. cit.,

5 SoraCE, D., "ll governo dell'economia" (cap. XX). Manuale di Diritto Pubblico (a cura di Amato, G. E Barbera, A.), II Mulino, Bolonia ${ }_{4} 1984$, págs. 903-57.

GIANNINI, M. S., "Relazione di sintesi" en La Costituzione economica, II Sole, Milán, 1985, págs. 19-24. Rescigno, P., "Saggio íntroduttivo" a I rapporti economici nella Costituzione, vol I, Il lavoro e la previdenza, Giuffré, Milán, 1987. 
en cuanto convive con otros a los que incluso se otorgan contenidos constradictorios.

Con este planteamiento se aborda la conexión entre los procesos de globalización y el marco constitucional de ordenación de la economía. El resultado es la ausencia de contradicción entre Estado social, con sus principios ordenadores del sistema económico, y los procesos en curso, que no son sino fruto de una adecuación inevitable de la evolución del sistema económico, pero sin confrontarse con el modelo constitucional en términos de ruptura.

Resulta ilustrativa de esta concepción, que ahora se presenta como dominante, el resultado de un seminario sobre la constitución económica celebrado en Milán a comienzos de 1996. En éste se sometía a debate, sobre la hipótesis de la tensión entre exigencias económicas e, incluso, transformaciones ordinamentales, y la Constitución económica resultante de la Carta del 47 , la conveniencia de la reforma de la Constitución en aspectos que afectaban al núcleo central de ésta. El resultado, sólo objetado minoritariamente, fue la no necesidad de introducir modificaciones formales en el texto Constitucional 6 .

Quizás la formulación de esta elasticidad sin fin del constitucionalismo económico del Estado social que mejor expresa este pensamiento sea la de Bognetti, curiosamente, sólo hace dos décadas en minoría en la doctrina. Este autor define así la conciliación: «la Constitución, en efecto, ha acogido aquél que es tradicionalmente el planteamiento privatista de la economía, que, aun interpretado de cierta forma, puede ser considerado absolutamente preeminente... La afirmación de principio según la cual el italiano es un Estado social tendencialmente válida todavía hoy, aun si dicho modelo ha querido especificarse en una serie de derechos sociales precisos que en realidad, están en su definición, ampliamente superados, a la luz de las actuales condiciones de hecho y de aquélla que será la situación futuran ${ }^{7}$.

No de muy diferente manera, casi desde el comienzo de nuestra andadura constitucional, se ha manifestado nuestra doctrina, don-

6 VV.AA., /l Federalismo fiscale. La costituzione economica, Giuffré, Milán, 1998, págs. 37-84.

7 BogNETTI, G., Intervención en el Seminario sobre la Constitución económica, en /I Federalismo Fiscale. Le costituzione economica, op. cit., pág. 47. 
de la neutralidad constitucional admite casi todas las hipótesis posibles $^{8}$.

La Constitución económica europea, tanto en los Tratados iniciales, como en su desarrollo posterior, presentándose como un ejemplo de adaptación a las exigencias de la globalización, tampoco es contemplada como contradictoria con el constitucionalismo social ${ }^{9}$.

Por nuestra parte, pretendemos rescatar la dimensión material de la constitución económica, restituyendo su valor conceptual, que se deriva de ser la emanación de la forma de Estado social10, planteamiento que, por otra parte, ha sido una constante en la doctrina hasta los años setenta11.

Sentar las bases de la Constitución económica del Estado social nos va a permitir contraponer ésta a la que emerge en el contexto de la globalización como ruptura del Estado social ${ }^{12}$.

Igualmente, esta confrontación de modelos nos posibilitará ejemplificar esta confrontación en el ámbito comunitario, donde, como han señalado algunos, se ha operado un proceso de desconstitucionalización de los ordenamientos económicos de los Estados, planteado como simple problema de relación interordinamental. Así, se ha señalado que los preceptos constitucionales que habilitan para cesiones de soberamía han introducido un modelo económico contrario al

8 MuÑoz MACHADO, S., "Las competencias en materia económica del Estado y de las Comunidades Autónomas. Aspectos jurídicos de la ordenación del sistema económico en la Constitución española de 1978». En La distribución de competencias económicas entre el poder central y las autonomías territoriales en el Derecho comparado y en la Constitución española (dirigido por E. García de Enterría), IES, Madrid, 1980, págs. 309-87.

9 LOPEZ BASAGUREN, A., "Constitución y Unión Europea: aporías en la integración europea", en El constitucionalismo en la crisis del Estado social, UPV/EHU, Bilbao, 1997, págs. 287-331.

10 MoscarinI, A., "Sussidiarietá e libertà eonomiche", en Trasformazioni della funzione legislativa. I. Vincoli alla funzione legislativa, Giuffré, Milan, 1999, págs. 245-321. También LoTITo, "Costituzione ed integrazione comunitaria: I reflessi sulla forma di stato, sul sistema di fonti e sulle forme di governo", en Riv. Ital. Diritto pubblico comunitario, 1995, págs. 737-772. pág. 30.

11 QUADRI, G., Diritto pubblico dell'economia, S. E. Napolitana, Napoli, 1977,

12 GRECO, R., "La crisi dei diritti e della legalità costituzionale nella dimensione sopranazionale dell'economia globale", en Quale Legalità. Atti del XII Congresso nazionale di Magistratura democratica, 1998, Franco Angeli, Milán, 2000, págs. 149-53. 
sistema constitucional ${ }^{13}$. Obviando, de esta manera, las exigencias de la Carta magna referidas a la reforma.

Parece pues que la construcción conceptual de la constitución económica, al menos en su concepción mayoritaria, permite una ductilidad de contenidos casi ilimitada que ha posibilitado una evidente regresión a uno de los polos de la confrontación que se manifestó en su origen.

Es una convención admitida que la génesis de concepto, en sus perfiles actuales, se sitúa en Weimar, en el marco del debate constitucional del Estado social ${ }^{14}$.

En ese momento, se confrontaron dos posiciones: una que conectaba directamente con la lectura socialdemócrata de la configuración de un nuevo modelo de Estado ${ }^{15}$, donde se conjugaban dos elementos, tanto una valoración del capitalismo y de su fase monopolista, como la teorización del carácter pacticio de proyecto Weimariano. Otra de inspiración liberal, cuyo único punto de ruptura con el liberalismo era la valoración de un intervencionismo público como mecanismo de garantía del funcionamiento del sistema.

Pues bien, las propuestas del ordoliberalismo parecen rescatadas por la teorización del Estado regulador ${ }^{16}$, modelo contrapuesto al desarrollado durante el período de consolidación y expansión del Estado social. La oposición entre Estado regulador y Estado interventor, materializado en el modelo asumido en el constitucionalismo económico de la Comunidad europea, no es sino expresión de la nueva constitución económica extendida en occidente, en contraste con el modelo del constitucionalismo social.

13 Greco, R., "La crisi dei diritti e della legalità costituzionale nella dimensione sopranazionale dell'economia globale», op. cit.

14 Cocozza, F. Profili di diritto costituzionale applicato all'economia, op. cit., pág. 145.

15 En la perspectiva jurídica, ver HeLLER, H., «El derecho constitucional de la República de Weimar. Derechos y deberes fundamentales", en Escritos políticos, Alianza Madrid, 1985, págs. 269-81. SINZHEIMER, "La concreta organizzazione dei consigli d'azienda", en Laboratorio Weimar, Ed. Lavoro, Roma, 1982, págs. 49-5. NeUMANN, F., "ll significato sociale dei diritti fondamentali nella costituzione di Weimar", en II diritto del lavoro fra democrazia e dittadura, II Mulino, Bolonia, 1983, págs. 121-40. 2000.

16 LA SPINE, A., y MAJONe, G., Lo stato regolatore, II Mulino, Bolonia, 


\section{LA CONSTITUCIÓN ECONÓMICA. PROBLEMAS CONCEPTUALES}

Hemos comentado que a pesar de una cierta generalización del término, el concepto de "Constitución económica» dista de ser pacífico, a su uso se ha opuesto su contradicción con el de Constitución, como concepto universalizante, problematizando de esta forma la aportación que realizó en el contexto de la transformación del constitucionalismo liberal.

Puede decirse que, desde la aparición misma de la reflexión de la relación entre Constitución y economia, el concepto ha sido controvertido. Weimar y sus aportaciones, base de la construcción doctrinal del Estado social, fueron también el marco del debate, no ya sobre la constitución económica, sino sobre la licitud del término. En la reconstrucción del concepto, la literatura iuspublicista sitúa en una misma línea de confrontación con el término a Schmitt y Neumann ${ }^{17}$ contrapuestas a una teorización representada por el iuslaboralismo alemán de esta época, en especial, por Sinzheimer. Sin embargo, las posiciones distan mucho de ser coincidentes, incluso su reconstrucción exige alguna matización.

Por otra parte, el replanteamiento actual de la cuestión ${ }^{18}$, a pesar de la alusión formal a Schmitt, poco tiene que ver con éste, sin que la reivindicación de un concepto unitario de constitución, que no permite autonomías estructurales en su interior (constitución económica versus constitución política), puede lícitamente vincularse a las posiciones Schmitt.

\subsection{Schmitt y Neumann}

La doctrina reconstruye la oposición de Schmitt al concepto de "constitución económica" sobre uná doble base: su concepto de constitución y su posición en el debate sobre la significación del artículo

17 Cocozza, F., "Riflexxioni sulla nozione di "Costituzione economica" ", en Il diritto della economia, 1992, n. ${ }^{\circ}$, págs. 71-90. Miccu, R., "Economia e Costituzione", una lettura della cultura giuspubblicistica tedesca", op. cit.

18 LUCIANI, M., Voz «Economia nel diritto costituzionale», en Digesto delle discipline pubblicistiche, vol. V, UTET, Turín, 1990. págs. 373-85. RESCIGNO, P., "Saggio introduttivo", en I rapporti economici nella Costituzione. Vol. I. I/ lavoro e la previdenza, Giuffré, Milán, 1987, págs. VII-XXIII. 
165 de la Constitución de Weimar19. La noción de "constitución económica" como concepto parcial pondría en peligro el concepto unitario de constitución política. Los efectos disolventes que incorpora la constitución económica se derivan de la presunción de su autonomía respecto a la constitución política, que incorporaría una lógica propia capaz de imponerse o perturbar los rasgos de la organización estatal contenidos en el texto constitucional. De esta forma, constitución económica se opone a su concepción de constitución como decisión fundamental global, en la medida en que ésta se manifiesta como unidad $^{20}$.

Por otra parte, sus posiciones sobre el alcance de los preceptos de la constitución de Weimar que regulan las relaciones económicas y, en especial, sobre la trascendencia de la constitucionalización de los consejos articulan su oposición a la constitución económica más como confrontación de modelos, que como reclamación metodológica.

La contradicción se establece entre la decisión constitucional sobre la estructura y organización del Estado, basado en el concepto de representación política y la introducción de elementos de carácter corporativo en los procesos decisionales ${ }^{21}$.

El ámbito de actuación del sistema de consejos, la política económica y sus funciones, consultivas esencialmente, así como la falta de desarrollo de las previsiones constitucionales, impiden construir sobre esta base una constitución económica. Así se afirma la primacía de la estructuración política del Estado contenida en la primera parte de la Constitución de Weimar. La solución a la tensión representación política versus representación de intereses sustenta su oposición a la constitución económica. La conformación del proceso decisional en el funcionamiento del Estado se convierte en el argumento central sobre la constitución económica. Ciertamente, parte de la doctrina de la época había hecho girar en torno a este precepto la construcción de conceptos como el de constitución económica o social ${ }^{22}$. Es dudoso que, al menos desde el punto de vista del iuslaboralismo de Weimar, se pretendiera establecer semejante contradicción. Constitución eco-

19 Cocozza, F., "Riflessioni sulle nozione...", op. cit.

20 SснмітT, C.. "Teoría de la Constitución", Revista de Derecho Privado, Madrid, 1934, vol. I, págs. 24-27.

21 SchmitT, C., La defensa de la Constitución, Tecnos, Madrid, 1983, págs. $161-66$.

22 SINZHEIMER, op. cit. 
nómica, más bien venía a destacar el reconocimiento constitucional de la autonomía colectiva y el papel otorgado a ésta. En base al reconocimiento de la libertad sindical y la negociación colectiva (art. 165.1) se valoraban las potencialidades transformadoras en las relaciones económico-sociales que se abrían con estas novedades. Primariamente, para esta doctrina, el acento debe ponerse en la libertad de coalición y su autonomía como motor de transformación, como el propio Neumann sostiene en su lectura de las posiciones de Sinzheimer ${ }^{23}$. La doctrina constitucionalista socialdemócrata tampoco fue radical en la virtualidad del sistema de consejos contenido en el artículo 165 , no hay más que ver las consideraciones de Heller al respecto ${ }^{24}$.

La afirmación de la primera parte de la Constitución de Weimar y su primacía, en cuanto decisión fundamental, articulada en torno a la Constitución del Estado de Derecho, tiene otra función, la confrontación de modelos, más allá del debate sobre la representación.

Pueden verse algunos efectos doctrinales de esta contraposición en las formulaciones de Forsthoff. La distinción entre decisión política fundamental, caracterizada, en la Constitución de Weimar, en torno a la idea de "Estado burgués de Derecho" ${ }^{25}$ y su contraposición a otros contenidos constitucionales que la componen ${ }^{26}$ y puedan, por tanto, comprometer el carácter unitario de la decisión, lleva a contraponer y adjudicar un papel subordinado a las disposiciones de carácter "socialista " ${ }^{27}$, respecto a los contenidos constitucionales del Estado burgués de Derecho, que asumen un papel de identificación de la decisión fundamental y dotan de coherencia al modelo28.

La contraposición de Forsthoff entre Estado de Derecho y Estado social resulta pues una construcción paralela a ésta, más aún, directamente inspirada en la caracterización schmittiana de los derechos, con la consecuencia de expulsar del ámbito constitucional al núcleo de la constitución económica.

Rastrear este paralelismo resulta interesante para ver cómo el intento de exclusión de la Constitución económica pretende, ante todo,

23 Neumann, F., op. cit.

24 HeLleR, H., "El Derecho Constitucional de la República de Weimar. Derechos y deberes fundamentales", en Escritos políticos, Alianza, Madrid, 1985, págs. 269-81.

Schmitt, C., Teoría de la Constitución, op. cit., págs. 27-88.

SCHMITT, C., Teoría de la Constitución, op. cit., págs. 149, 210.

Schmitr, C., Teoría de la Constitución, op. cit, pág. 196.

28 Schmiт, C., Teoría de la Constitución, op. cit., pág. 205. 
confrontar modelos. No es de extrañar, por tanto, que para Forsthoff, Weimar sea el paradigma de los efectos perversos de la introducción constitucional de contenidos ajenos a los propios del Estado de Derecho ${ }^{29}$.

Tampoco resulta sorprendente la contraposición entre Constitución política y formas de representación de intereses ${ }^{30}$.

El elemento determinante en la caracterización del constitucionalismo moderno es la forma de la decisión política que se expresa en la representación política. Las organizaciones de representación de intereses, en especial los sindicatos, asumiendo funciones políticas, participando en los procesos decisionales, perturban la lógica de la representación, incluyendo elementos espúreos en el modelo constitucional. Alude Forsthoff al debate de Weimar para ilustrar la tensión entre representación política y de intereses ${ }^{31}$, del que se hace eco, asumiendo las posiciones de Schmitt. «La esencia de una «Doctrina de la Constitución" construida sobre la Ley Fundamental se muestra entonces por lo que es: la ampliación de los modos de formación de la voluntad del Estado, la disolución de la representación y el abandono del principio de separación han demolido la constitución como edificio lógico. La unidad política de la República federal no tiene su fundamento exclusivo en la constitución y en un ordenamientó constitucional: este fundamento se encuentra sobre todo en la interacción de innumerables factores sociales $y$ estatales que escapan a cualquier consideración que pretende ser sistemática" ${ }^{32}$. Como puede verse, las consideraciones sobre la representación de intereses (los sindicatos) y el principio de separación (entre Estado de Derecho y Estado social), articulan de forma paralela a la formulación de Schmitt, la exclusión de la constitución económica.

Principio de separación, expresado en la contraposición entre Estado de Derecho y Estado social ${ }^{33}$, que establece, tanto la superioridad del núcleo constitucional heredero del Estado de Derecho bur$169-95$.

29 MANGIA, A., "Postfazione»a L'ultimo Forsthoff, Cedam, Milán, 1995, págs.

30 Forsthoff, E., "Sulla situazione attuale di una dottrina della costituzione", en L'ultimo Forsthoff, op. cit., págs. 105-43.

31 FoRSTHOFF, E., "Sulla situazione attuale di una dottrina della costituzione", op. cit.

32 ForsthofF, E., "Sulla situazione attuale di una dottrina della costituzione", op. cit.

33 Forsthoff, E., Stato di diritto in trasformazione, op. cit. 
gués, como la subalternidad de los derechos sociales, situación ésta que impide la configuración de una constitución económica vinculada a la forma de Estado social, negada desde el punto de vista constitucional.

Diferente es la posición de Neumann, que sólo tangencialmente puede relacionarse con Schmitt a pesar de la vinculación que se establece entre ambos por su tratamiento de la representación corporativa y su oposición a la representación política, cuestión que tampoco se articula de la misma manera ${ }^{34}$. En todo caso, la propuesta de Neumann es sustancialmente distinta y se inspira en las tesis socialdemócratas. Puede resumirse en los siguientes términos:

- Neumann no niega la posibilidad de la constitución económica, ni su existencia; su mayor problema, en orden a su afirmación real, es el contraste entre el diseño constitucional y su materialización ${ }^{35}$. Es decir, la dificultad de resolver la tensión entre constitución formal y la constitución material postrevolucionaria.

- En el discurso teórico, no obstante, vincula la regulación constitucional weimariana a las transformaciones económicas propias del capitalismo monopolista. Su base de partida es siempre el fin del capitalismo concurrencial.

- Constitución económica no puede oponerse a Constitución política ${ }^{36}$. No sólo reclama de esta forma la unidad del proyecto constitucional, que en su construcción no es ajena a la idea de "Estado de derecho social» ${ }^{37}$, sino su función ordenante. La afirmación de la superioridad de la constitución política no sólo opera en el debate democracia representativa-representación corporativa, sino que tiene la función de dotar de efectos totalizantes al modelo global contenido en la constitución. La revalorización de la segunda parte de la constitución (derechos y libertades y en especial la regulación de la economía) expresa esta idea.

34 NeumanN, F., "On the preconditions and the legal concepto of an economic constitution", en Social democracy and the rule of Law $(O$. Kirchiheimer y $F$. Neumann), Allen \& Unwin, London, 1987, págs. 44-65.

35 NEUMANN, F., "On the preconditions...", op. cit.

36 NEUMANN, F., "On the preconditions...", op. cit.

37 NEUmanN, F., "ll significato sociale dei diritti fondamentale...", op. cit. 
- Concilia su interpretación del artículo 165 con las exigencias de la democracia parlamentaria, evitando su contradicción. Para ello, como hemos dicho, alude incluso a las formulaciones de Sinzheimer, que permiten esclarecer el alcance de la vinculación entre el sistema consejista y la constitución económica.

Ciertamente, las intervenciones de este iuslaboralista y representante socialdemócrata en la Asamblea constituyente dificultan utilizar el artículo 165 como base de oposición a la idea de Constitución económica. "El otro extremo está constituido por una tesis muchas veces discutida en el pasado, la idea de la institución de una Cámara profesional junto al parlamento político... La asamblea constituyente ha rechazado también esta hipótesis, sobre todo porque, si los portadores de intereses económicos hubiesen debido encontrar en una Cámara especial una instancia decisional equiparada al parlamento político, toda la política estaría subordinada a la economía... La vía que la comisión constituyente ha encontrado... consiste en asegurar a los Consejos una plena influencia sobre la política, pero ningún poder decisional sobre el plano políticon ${ }^{38}$.

La ubicación del Consejo de Economía en el ámbito de la función consultiva, reforzado con la iniciativa legislativa, deshace la confrontación pretendida.

La Constitución económica se inserta en la constitución cobrando su sentido de la unidad del proyecto constitucional. Tiene como objeto evidenciar los elementos fundamentales del proyecto constitucional, que se manifiestan en ámbito económico. De esta forma, la Constitución económica caracteriza, como novedad, al constitucionalismo social. "La constitución económica está dirigida a proveer la posibilidad de alguna intervención social del Estado en el curso natural de la actividad económica, esto es, en el marco de la libertad económica» ${ }^{39}$. Intervención del Estado consagrada constitucionalmente como una lógica superadora del liberalismo.

Las ideas fundamentales que articulan su concepto de Constitución económica vienen representadas por la intervención del Estado

38 SINZHEIMER, H., "Relazione all'asamblea costituente (1919", en Lavoratorio Weimar, E. Lavoro, Roma, 1982, págs. 45-7.

39 NeumanN, F., "On the preconditions and legal...", op. cit. 
determinada por el vínculo social ${ }^{40}$ y el gobierno democrático de la economía, es decir, el control democrático del mercado ${ }^{41}$.

Este control descansa en dos ejes: el Estado y las organizaciones de intereses que operan en el mercado. El reconocimiento constitucional de los sujetos económicos, en especial, de los sindicatos, y su trascendencia, vinculan su propuesta, mucho más articulada, con la del iuslaboralismo weimariano, que se confunde con la democracia económica.

\subsection{La nueva oposición entre constitución y Constitución económica}

Aun pudiendo afirmar la superación de varias de las cuestiones planteadas en el debate sobre la cuestión en Weimar, la oposición al concepto de Constitución económica emerge en la doctrina, en los últimos tiempos, con un significado que permite ciertas conexiones.

Ciertamente, en la doctrina alemana la constitución económica sólo ha tenido la contestación derivada de la construcción jurisprudencial de la neutralidad constitucional, que pretende desvincular al orden Constitucional de modelos preestablecidos, en una suerte de asepsia jurisprudencial inexistente.

La doctrina italiana, especialmente en la década de los ochenta del siglo pasado, ha resucitado el debate sobre la licitud del concepto. Los argumentos giran en torno a las ideas de unidad y coherencia constitucionales.

Las dos acepciones que la doctrina italiana da al término "constitución económica", una referida al conjunto de las normas constitucionales en materia económica y otra como complejo normativo con contenidos propios ${ }^{42}$, plantean el problema de la autonomía de la constitución económica y, por tanto, sus relaciones con la Constitución concebida como unidad.

La Constitución económica es vista, ahora también, como potencialmente contrapuesta a la Constitución política coincidiendo, al menos formalmente, con el debate Weimariano. La contradicción no

\footnotetext{
40 NeUmANN, F., "ll significato sociale dei diritti fondamentali...", op. cit.

41 NeUMANN, F., "On the preconditions and legal...", op. cit.

42 LUCIANI, M., Voz "Economia nell diritto costituzionale", op. cit.
} 
se articula sobre contenidos adjudicados al concepto, sobre los que entablar un debate doctrinal, sino que se hacen derivar de la propuesta conceptual peligros desestabilizantes para la concepción constitucional, especialmente la gestada en el Estado social.

Puede que en la contraposición constitución versus constitución económica subyazca una cuestión no planteada explícitamente, es decir, la contradicción entre la nueva constitución económica y la constitución, en este caso italiana, vinculada a la tradición del constitucionalismo social. Pero esta cuestión no es sino la de la tensión entre constitución material del Estado postsocial y la constitución formal existente; no puede formularse como un problema terminológico con trascendencia metodológica.

Tres son las cuestiones que plantea Luciani ${ }^{43}$ respecto a esta cuestión, la concepción de la constitución económica como un orden normativo autónomo, es decir, dotado de principios propios que se contrapondrían, al menos potencialmente, a la constitución.

En segundo lugar, plantea que la aceptabilidad en el constitucionalismo actual de la autonomía normativa de este sector, equivaldría a la recuperación del principio liberal de la separación de las esferas de la política y de la economía. Por último, entiende que la autonomía normativa de la constitución económica afecta a la constitución como proyecto general. Compromete, por tanto, su unidad y coherencia, afectando a la propia teoría constitucional. Como es evidente, la crítica descansa sobre la autonomía normativa del concepto, cuestión esta que puede no compartirse.

También Rescigno ${ }^{44}$ articula una crítica al uso del término con coincidencias sustanciales, "pero voces autorizadas, últimamente, en sede de propuestas y estudios de las reformas institucionales, han señalado el escaso rigor de una dicción que, entre otras, parece inducir, y es esto lo que suscita reservas y censuras, a un sectorial reconocimiento del texto constitucional, contra el evidente carácter de unidad y coherencia del diseño trazado por los constituyentes» 45 .

La interconexión de los preceptos constitucionales y su vinculación a un único sistema de principios impediría establecer una autonomía sectorial en el marco de la Constitución.

43 LUCIANI, M., Voz "Economia nel diritto costituzionale», op. cit.

44 RESCIGNO, P., "Saggio introduttivo..." a I rapporti economici..., op. cit.

45 Rescigno, P., "Saggio introduttivo..." a I rapporti economici..., op. cit. 
La dificultad de distinguir y autonomizar lo social de lo económico e incluso el sistema de derechos, por no decir de la influencia de las cláusulas generales, en especial, el artículo 3.2, impedirian un tratamiento diferenciado de la economía.

Rescigno, en el contexto de su discurso sobre la constitución económica, aborda la relación entre constitución material y constitución formal, ámbito, a nuestro juicio, al que había que trasladar la tensión entre previsiones constitucionales y constitución económica. Sin embargo, lo hace al hilo de una cuestión tangencial que, como correctamente plantea, no entra dentro de la tensión que existe entre dato normativo y fáctico capaz de transformar al primero. La cuestión se plantea en relación a la inactuación del artículo 39 de la Constitución italiana: la regulación del sindicato y negociación colectiva, y la conformación de un ordenamiento intersindical en contraste con el precepto citado.

Ciertamente, en este caso, el problema estriba en el alcance que se dé al ordenamiento intersindical con relación a la Constitución y, en especial, respecto al Estado social. Como bien señala este autor, el correcto uso del término "Constitución maferial" permite resolver la cuestión plateada. "Se expresa la opinión de que la inactuación de un programa (y ciertamente las normas sobre la organización sindical revestían naturaleza programática y no inmediatamente preceptiva) no confiere necesariamente, al sistema de reglas que continúa o entra en vigor, dignidad o rango de constitución material's 46 . Al contrario de to que sugiere un planteamiento simplista, el ordenamiento intersindical supone no el asentamiento de una constitución material nueva en contraste con el texto del artículo 39, sina la recuperación, en este ámbito, de la lógica de la constitución material del Estado social, en oposición a la política practicada en los años 50 , cuya situación factual era, en este caso, no conciliable con los principios de la forma de Estado social. El ordenamiento intersindical no fue sino el instrumento de recomposición de una constitución material del estado social antes en entredicho ${ }^{47}$.

Luciani, aun no planteando el problema en términos de constìtución material, apunta la cuestión fundamental, pero la resuelve en una tensión conceptual que supone una vía de escape al problema

46 Rescigno, P., "Saggio introduttivo"..., op. cit.

47 Maestro Buelga, G., La Constitución del trabajo en el Estado social, Ed. Comares, Granada, 2002, págs. 125-29. 
planteado. Su apelación a la unidad y coherencia constitucional le lleva a establecer principios que presiden el proyecto constitucional que predeterminan cualquier análisis de las normas económicas e impiden la afirmación de la constitución económica. Dichos principios pueden formularse, de manera general, como el vínculo social del sistema económico y de la acción pública. Pero esos principios no son otra cosa que la constitución económica, claro está, del Estado social. Desde esta perspectiva, no hay autonomía, entendida como contradicción entre proyecto constitucional unitario y Constitución económica.

Sí la hay, y la contradicción se expresa con claridad notoria, entre la nueva constitución económica, por usar la formulación de Cassese $e^{48}$, su reconstrucción y sus principios y la constitución económica del Estado social. Pero, en este caso, no se trata de autonomía de la constitución económica, sino de ruptura de la Constitución material del Estado social, de la que los nuevos principios económicos son su manifestación más evidente.

Este será el planteamiento que seguiremos en el análisis de las cuestiones a abordar en este trabajo.

\subsection{El concepto de constitución económica}

En nuestra opinión, podemos distinguir entre dos concepciones de la constitución económica, diferenciación que, como veremos, no está exenta de problemas. La distinción alude a un concepto fundamentalmente descriptivo y otro que, recuperando el debate en torno a la unidad y coherencia constitucional antes mencionado, vincula a la constitución económica con un modelo que se entiende acogido por la norma constitucional, se configura como un concepto sustancial.

Ciertamente, la primera de las concepciones parece mayoritaria, además en su desarrollo se ha vinculado a otras nociones paralelas que han dotado de gran ductilidad al propio concepto.

La concepción descriptiva permite una reconstrucción permanente de ésta, en cuanto vinculada a un conjunto de normas que incorporan principios contradictorios, en el marco del constitucionalismo social. De esta forma, en estas formulaciones está presente aquello que constituía la crítica conceptual ya comentada, es decir, la autonomía

48 CASSESE, S., La nuova costituzione economica..., La Terza, Bari, 1995. 
de la constitución económica respecto a la constitución y su proyecto. La constitución económica descriptiva se desvincula de la forma de Estado, aunque fuese en este marco en el que surgió el propio concepto. Igualmente, para cumplir su función se asocia, justificando su formulación, con propuestas como la neutralidad constitucional en la materia, con la que se quiere romper el vínculo entre constitución económica y forma de Estado, proponiendo la inexistencia de modelos constitucionales cerrados, que condicionan la regulación económica.

Ciertamente, neutralidad constitucional en material económiça, por usar la expresión acuñada por la doctrina y jurisprudencia alemana 49 , no es sin más identificable con un concepto descriptivo de constitución económica, pero en la construcción de esta última reclama para su fundamentación la apertura constitucional sin referencia a programas que la determinen.

Sobre la concepción descriptiva de la constitución económica se organiza pues la compatibilidad entre la nueva constitución económica y la constitución formal heredera del constitucionalismo social. La secuencia descriptiva de la evolución de la constitución económica desde el liberalismo hasta nuestros días propuesta por Cassese es ilustrativa de esta concepción ${ }^{50}$. Igualmente su distinción entre las distintas concepciones de la constitución económica, a pesar de su intento diferenciador, no supera esta concepción descriptiva ${ }^{51}$.

a) La Constitución económica descriptiva. Como hemos dicho, esta concepción es mayoritariamente compartida en la doctrina no sólo española, sino en nuestro entorno jurídico-cultural. Éste es el concepto que recoge Cocozza como predominante en la doctrina italiana: "la expresión venía, por lo demás, utilizada en sentido meramente descriptivo, para indicar las disposiciones de la constitución formal relativas a las relaciones económicas: aquel de Constitución económica había devenido, en suma, un concepto neutral, utilizado para describir sintéticamente el ordenamiento jurídico (en su nivel más alto: aquel constitucional) del proceso económico» ${ }^{52}$.

49 PAPIER, J. J., "Ley fundamental y orden económico" (Cap. XI). Manual de Derecho constitucional, M. Pons, Madrid, 1996, págs. 561-612; STOBER, R., Derecho administrativo económico, Ministerio para las Administraciones Públicas, Madrid, 1992, págs. 63-8.

50 CASSESE, S., La nuova costituzione economica, op. cit., págs. 7-27.

51 CASSESE, S., La nova costituzione economica, op. cit., págs. 3-5.

52 CAssese, S., Profile di diritto costituzionale ..., op. cit., pág. 144. 
También, en este caso, se vincula concepción descriptiva a la neutralización de la constitución económica, entendiendo que ésta legitima metodológicamente una construcción conceptual desvinculada de la forma de Estado.

Semejante concepción está presente en la literatura española que, de su génesis histórica, ha pasado este concepto a referirse a un conglomerado normativo. La superación de la confrontación histórica en torno al término y su consiguiente neutralización ha posibilitado la transformación. "Como tal concepto de combate se mantendrá hasta que el "peligro ruso" desaparezca del horizonte, quedando a partir de ese momento como un concepto neutral, puramente descriptivo de las normas constitucionales relativas a la ordenación del proceso económico» ${ }^{53}$.

En nuestra doctrina, esta concepción viene avalada e impulsada por la jurisprudencia constitucional. La STC, muchas veces citada, 1/1982 asienta este concepto: “En la Constitución española de 1978, a diferencia de lo que solía ocurrir con las constituciones liberales del siglo XIX y de forma semejante a lo que ocurre en más recientes constituciones europeas, existen varias normas destinadas a proporcionar el marco jurídico fundamental para la estructura y el funcionamiento de la actividad económica: el conjunto de todas ellas componen lo que suele denominarse la constitución económica o constitución económica formal» (Fj. n. ${ }^{\circ}$ 1). Esta definición viene precedida por contribuciones que marcan su conexión con la «neutralidad constitucional». La constitución económica en la constitución no garantiza necesariamente un sistema económico ni lo sanciona, permite el funcionamiento de todos los sistemas que se ajustan a los parámetros constitucionales y sólo excluye aquellos que sean contradictorios con los mismos. Por ello, nos parece que la referencia del artículo 38 a la libre empresa en el marco de la economía social de mercado permite un sistema de economía plenamente liberal, una economía intervenida y una economía planificada por lo menos a través de una planificación indicativa" (voto particular de Luis Díez Picazo a la STC 36/1981).

Esta línea jurisprudencial ha sido ampliamente acogida por la doctrina, convirtiéndose en la referencia mayoritaria ${ }^{54}$.

53 Pérez Royo, J., Curso de Derecho Constitucional, M. Pons, Madrid, 1996, pág. 231.

54 Martín Retortillo Baquer, S., Derecho administrativo económico, La Ley, Madrid, 1988, vol. I, pág. 29. GIMENo FeLIU, J. M., "Sistema económico y derecho a la libertad de empresa versus reservas al sector público de actividades económicas", en RAP, 1994, n. ${ }^{\circ} 135$, págs. 149-211. 
La doctrina alemana ofrece matices no desdeñables respecto a los planteamientos anteriores. En primer lugar, por la influencia doctrinal del debate surgido en el período de entreguerras, que se prolongó durante los años cincuenta. En segundo lugar, por la referencia normativa: como se sabe, la Ley Fundamental carecía de referencias normativas respecto a la ordenación de la economía. Por ello, el debate en gran medida se ha centrado en la existencia o no de una constitución económica. Sin embargo, en torno a la cuestión de la neutralidad constitucional se han articulado propuestas no muy diferentes.

b) La neutralidad Constitucional. Resulta evidente que neiutralidad constitucional, a pesar de la literalidad equívoca de las formulaciones, no quiere decir inexistencia de alguna predeterminación constitucional respecto al sistema económico, más bien significa la admisión de un grado importante de apertura que, sin embargo, funciona entre límites definidos. La cuestión de la neutralidad constitucional en materia económica se plantea pues en los términos que establece Martín-Retortillo ${ }^{55}$. No hay constituciones neutrales, todas interiorizan un sistema económico frente al cual no es posible una interpretación antitética, lo que no significa admitir un margen de disponibilidad constitucionalmente reconocido.

El reconocimiento de la ausencia de "soluciones únicas, exclusivas» ${ }^{56}$ establece el ámbito de la política, de las salidas al conflicto, dentro de los límites del sistema.

Aunque la cuestión asi formulada sería inobjetable, es más, no sería sino la manifestación de las características constitucionales del Estado social, la propuesta doctrinal y jurisprudencial trasciende a este planteamiento. La apertura que se proclama de los textos constitucionales supone una desvinculación de la forma de Estado social, en la medida en que la pluralidad de opciones admitidas se confrontan con ésta.

La tesis de la neutralidad constitucional en material económica resulta formulada, en su expresión más nítida, por la jurisprudencia

55 Martín Retortillo Baquer, S., "La “Constitución económica" en el texto de la Constitución española de 1978», en Constitución y Constitucionalismo hoy, Fundación Manuel García Pelayo, Caracas, 2000, págs. 149-74.

56 Martín Retortillo Baquer, S., "La “Constitución económica” en el texto de la Constitución española de $1978 \% . . .$, op. cit. 
constitucional alemana y de ahí se traslada a la doctrina que la recibe mayoritariamente. Ciertamente, la Ley Fundamental de Bonn rompe con el proceso abierto en Weimar y apenas introduce, especialmente en sus primeros momentos, referencia alguna a la actividad económica. En la doctrina, esta ausencia ha sido puesta en relación con las particularidades del proceso constituyente de la República Federal ${ }^{57}$. Para los constituyentes alemanes, la ley fundamental tenía un carácter provisional que aconsejaba postponer decisiones de esta índole afectadas por un alto grado de incertidumbre en su evolución. Esto condujo a un acuerdo básico que debía girar en torno a la idea de protección de los derechos fundamentales, obviando cuestiones que resultaban reenviadas a un futuro indeterminado. Si los debates parlamentarios situaban la relación constitución-economía en forma de compromiso dilatorio ${ }^{58}$, el Tribunal Constitucional sancionó la situación, construyendo sobre la literalidad constitucional la teoría de la neutralidad.

La jurisprudencia constitucional alemana, prácticamente desde sus inicios, se confronta con la idea de constitución económica como decisión, lo que no quiere decir que, de facto, no construya un modelo sobre la base de la trasposición al ámbito económico del sistema de derechos, al que, sin embargo, se le desvincula de referencias globales.

La formulación de la neutralidad constitucional se realiza tempranamente, en la primera mitad de los cincuenta del siglo pasado y se mantiene inalterada. Los términos iniciales son especialmente ilustrativos. "La Ley Fundamental no garantiza ni la neutralidad políticoeconómica de los poderes legislativos $y$ ejecutivos ni tampoco un modelo de economía social de mercado que sólo deba funcionar mediante instrumentos que sean conformes al mismo. La neutralidad político-económica de la Ley Fundamental consiste en que el legislador constitucional no se ha declarado de ningún modo expreso a favor de un determinado sistema económico. De este modo, se posibilita que el legislador persiga en cada caso una política económica adecuada a sus objetivos, siempre y cuando sea respetada la Ley Fundamental... Por ello, desde el punto de vista constitucional, carece de toda trascendencia que la ley sobre ayudas a la inversión esté en consonancia con el actual ordenamiento social y económico y que los instrumen-

57 REICH, N., Mercado y derecho, Ariel, Barcelona, 1985, págs. 74; PAPIER, J. J., "Ley fundamental y orden económico", op. cit.

58 PAPIER, J. J., "Ley fundamental y orden económico", op. cit. 
tos utilizados para la dirección de la economía sean conformes o no con el funcionamiento del mercado" (Sentencia de 20 de julio de 1954).

Esta formulación se mantiene incluso después de las modificaciones constitucionales de 1967 y de la consolidación tanto de las políticas económicas, como de las intervenciones normativas que se mantuvieron hasta los años 80 . De esta línea inalterada es ejemplo la sentencia sobre la cogestión de 1 de marzo de 1979: "La ley Funda. mental no contiene determinación o garantía del modelo económico, sino que encomienda el régimen económico al legislador, quien decidirá libremente dentro de los márgenes tratados por la Ley Fundamental, sin precisar para ello de mayor fundamento que su genérica legitimación democrática».

Como hemos aludido, la neutralidad constitucional, ni siquiera en una construcción como la del Tribunal constitucional alemán significa que no tiene límites, sino que, sobre esta base, se construye una constitución económica sin referencias generales, modelos, que condicionen a los agentes públicos y privados. Se convierte el ámbito económico en un espacio disponible, donde su regulación constitucional sólo opera como juego de límites-garantías en la preservación del sistema, diluyéndose los elementos constitucionales de vinculación al sistema económico.

La constitución económica no opera como la constitución, es decir, como sistema de garantías, noción esta vinculada a las trasformaciones constitucionales que impone el Estado social ${ }^{59}$. Al configurarse la constitución como espacio disponible tiende a funcionar en lugar de como mecanismo de integración del conflicto, mediante un sistema de garantías recíprocas, que sólo se manifiesta de manera precaria y defectuosa, como un sistema unidireccional que se materializa mediante la noción de límite que se actúa a través de los derechos del sujeto económico privado constitucionalizados.

c) La noción sustancialista de la Constitución económica. A diferencia de la concepción descriptiva, la noción sustancialista presupone la remisión a un modelo constitucionalmente recibido, que actúa normativamente, es decir, disciplinando y dotando de coherencia a las normas, no sólo constitucionales, impidiendo su consideración autónoma.

59 GIANNINI, M. S., "La rilevanza costituzionale del lavoro", en Rivista Giuridica del Lavoro, 1949, págs. 1 y ss. 
Como hemos podido ver, esta cuestión estaba presente en el debate weimariano, pero reaparece en los preámbulos del constitucionalismo de la II. postguerra. La primera referencia obligada, desde esta perspectiva, debe serlo la llamada corriente ordoliberal, representada por la escuela de Friburgo.

Recuperando y superando el debate suscitado en Weimar sobre la constitución económica introduce un nuevo planteamiento metodológico. El modelo de referencia lo constituye la economía de mercado, dentro de la cual deben encontrar su sentido las normas del ordenamiento que disciplinan la economía.

De los dos modelos de ordenación de la economía existentes, argumentaban los teóricos de la escuela de Friburgo ${ }^{60}$, la economía centralizada y la de mercado, esta última es la única conciliable y conforme a los principios de Estado de Derecho democrático ${ }^{61}$. De esta forma, la economía de mercado se constituye en referencia constitucional, en modelo normativo de ordenación de la economía. La compatibilidad entre principio constitucional fundamental al Estado de Derecho democrático y economía de mercado dota a ésta de un status de modelo normativo que se contagia de la supremacía constitucional.

La Constitución económica, sentada la conexión constitucional, se perfila ahora paralelamente al propio concepto de constitución, como decisión global fundamental y con ello adquiere la valencia jurídica primaria. Naturalmente, no se presentan problemas de compatibilidad con la constitución política en la medida en que se ha realizado previamente la armonización vía identificación Estado de Derecho, economía de mercado.

Böhm, el jurista más representativo de la escuela, define, con la asunción implícita de este esquema, la constitución económica como "decisión global sobre el ordenamiento de la vida económica de una comunidad»62.

El problema que planteaba la jurisprudencia constitucional alemana de la postguerra respecto a la falta de decisión constitucional viene, en esta interpretación, resuelta por la vinculación del modelo

60 EUCKEN, W., «El problema político de la ordenación», en La economía de mercado, Sociedad de Estudios y Publicaciones, Madrid, 1963, págs. 25-80.

61 Miccú, R., "Economia e costituzione", una lettura della cultura giuspublicistica tedesca", op. cit.

62 Mıccú, R., op. cit., citando a BöHM en su definición más conocida. 
político con un orden económico determinado, de tal forma, que aunque la escuela comienza su andadura en los años treinta del siglo pasado, la influencia de la propuesta se extiende, como paradigma dominante, durante las décadas siguientes a la ley fundamental. Incluso su fórmula "economía social de mercado" encuentra una "suerte» de constitucionalización por su recepción en el proceso de reunificación alemana63.

No es de extrañar que la «economía social de mercado» se convierta en el paradigma dominante puesto que su aparente contradícción con las posiciones declaradas por el Tribunal constitucional alemán no pueden ocultar una coincidencia profunda.

Efectivamente, el Alto tribunal germano construye, a través del sistema de límites extraídos de los derechos fundamentales de la Ley Fundamental y de sus principios (Éstado de Derecho), congruente con la fórmula de "economía social de mercado", un concepto implícito de constitución económica. Por ello la declaración sobre la neutralidad constitucional debe ser atenuada por la lectura jurisprudencial de la dimensión económica de los derecfios fundamentales. De esta forma, también jurisprudencialmente se realiza la compatibilidad entre constitución política (Estado de Derecho democrático) y orden económico. No es extraño que la doctrina relativice las reiteradas declaraciones jurisprudenciales sobre la neutralidad: "Tal vez la ley Fundamental no contenga en las citadas garantias decisión política básica alguna que haga específica referencia a la economía, pero eso no es lo decisivo. Lo esencial es que el régimen constitucional de Derechos fundamentales reconoce al individuo, como persona juridica, una determinada participación en los procesos sociales y económicos... Al individuo le debe ser posible participar en la vida social y económica no sólo a la hora de concretar, a modo de ejecutor público, los aspectos más sutiles de la política estatal, sino igualmente - de manera responsable y autónoma y también en aras del propio beneficio- en la configuración del régimen jurídico, social y económico» ${ }^{64}$.

El ordoliberalismo, a diferencia de la posición tradicional liberal, aún dentro del marco descrito, entiende que la ordenación de la eco-

63 Así, el Tratado para la creación de la "Unión monetaria económica y social entre la República Federal de Alemania y la República Democrática Alemana» establece que la base de la unión económica es la «economía social de mercado como régimen económico común de ambas partes del tratado" (art. 1.3̣).

64 PAPIER, J. J., "Ley Fundamental y orden económicon, op. cit. 
nomía sí es un problema político en el que las instituciones públicas, el Estado, deben cumplir un papel fundamental. Esta es la principal aportación de esta corriente, que propicia el nuevo debate sobre la constitución económica que aparece ahora relanzado desde un frente que poco antes hacia inviable la conexión economia-constitución.

Ciertamente, aun reconociendo la preeminencia del privado en la actividad económica, como corresponde a la centralidad del mercado, la función del Estado ya no es de garante externo, sino de definidor del mismo. El mercado pierde sus connotaciones de orden natural ajeno y refractario a la intervención política, para convertirse en objeto de regulación-definición institución, así se realiza una nueva conexión entre política y economía ajena a la tradición liberal65, la economía deviene entonces problema constitucional, en cuanto es función pública su ordenación, es decir, las bases del diseño de su funcionamiento. El abandono de la concepción iusnaturalista del mercado es el fundamento filosófico-teórico de la nueva aproximación ordoliberal.

En el modelo teórico, la propuesta es la intervención estatal en la configuración de las reglas de funcionamiento del mercado, en especial, la garantía de la competencia que no puede ser confiada a las tendencias monopolistas inherentes a su funcionamiento. La ordenación del mercado, a través de la limitación del poder de sus agentes, es ya una función pública que, ahora, se inscribe en la lógica del constitucionalismo político de defensa de la libertad. Esta conexión entre Estado pluralista democrático y garantía de la libertad en el mercado, permite a Böhm realizar la conexión entre constitución y economia ${ }^{66}$. La propuesta fundamental será la de la regulación del mercado como garantía de la libertad y de la concurrencia, la preservación de la igualdad frente a la acción del "mercado natural». "Desde el punto de vista constitucional el sistema de libertad de empresa constituye una constitución de la vida económica en sentido político; consecuencia de esto es que la introducción de este sistema expresa una "decisión global" sobre el modo y la forma del proceso económico-social de cooperación en el sentido en que Carl Schmitt designa la constitución del Estado como "decisión global sobre el modo y sobre la forma de la

65 DI NeLLA, L., "La scuola di Friburgo, o dell'ordoliberalismo", en Diritto ed economia. Problemi e orientamenti teorici, VV.AA., Cedam, Milán, 1999, págs.171-227.

66 Miccú, R., "Economía e costituzione...", op. cit.; CARonNA, F., "Qualque spunto sull'evoluzione della costituzione economica dell'Unione European, Ars interpretandi, 2001, n. ${ }^{\circ} 3$, págs. 271-94. 
unidad política". Y más concretamente el sentido, el contenido material de esta decisión absolutamente unívoca es que la dirección de la vida económica ha sido sustraída de las manos de la política y de la comunidad social y confiada a un procedimiento abstracto. Este procedimiento es el de la competencia» ${ }^{67}$. Respecto a las implicaciones constitucionales de la competencia señala Böhm: "La economía de mercado se concilia con la constitución democrática del Estado no sólo porque sus tareas están reducidas al mínimo de la forma más económica posible..., sino también porque se combina a la perfección con la democracia política en cuanto aquella expresa un proceso democrático.

Democrático es también el orden de la competencia, que respeta los deseos de consumo de los ciudadanos en la forma y en los contenidos en los cuales son hechos valeri 68 . Aunque no sólo justifiquen la intervención garante de la concurrencia ${ }^{69}$, ésta es la puerta de apertura que, inevitablemente deberá conducir a admitir intervenciones correctoras en el ámbito social que, sin embargo, no deben comprometer al mercado como elemento central de distribución.

De esta forma, se llega a configurar un espacio de relación público-privado complejo y potencialmente abierto. La definición más acabada de la "economía social de mercado" es la fórmula MüllerArmack ${ }^{70}$ sobre la base de la combinación de tres elementos: regulación del mercado como garantía de la competencia, intervención social y la intervención de coyuntura. Veamos cómo se produce la interacción de estos elementos.

La base de partida, común por to demás a toda la escuela, es la crítica a la dirección centralizada de la economía, incluso a la experiencia de la inmediata postguerra en la Alemania occidental, ésta conduce a la afirmación de la economía de mercado. Sobre la base de la indiscutibilidad de sus principios, se realiza la armonización entre los elementos señalados. "La ordenación de la economía de mercado presupone, si ha de ser duradera, ciertos elementos de dirección central. Se trata de medidas estatales para la creación y el aseguramiento de la economía de competencia. La creación de un derecho social es tam-

67 BöHM, F. Citado por Di Nella, L., en "La scuola de Friburgo...», op. cit.

68 BöHM, F. Citado por DI NelLA, L., en "La scuola de Friburgo...", op. cit.

69 EUCKEN, W., "El problema político de la ordenación», op. cit.

70 Muller-ARMACK, A., "Las ordenaciones económicas desde el punto de vista social», en La economia de mercado, op. cit., págs. 81-126. 
bién, sin duda, un presupuesto necesario del funcionamiento de la economía de mercado. En una economía de mercado así asegurada hay numerosos caminos para realizar tareas sociales, sin perturbación del mecanismo de mercado. Así como una intervención directa en el mecanismo de precios es, casi siempre, perjudicial, no existen inconvenientes para una desviación político-social de los ingresos, mientras la dirección respete aquellos límites dentro de los cuales se conserven suficientemente los estímulos del mercado" ${ }^{71}$. Establecida la subordinación de la política social a la lógica del mercado que actúa como límite de la ordenación social, queda por ver cómo se articula la intervención de coyuntura: "La última tarea, y quizá la decisiva, será la del aseguramiento de la coyuntura. Tendremos que renunciar, sin duda, a los excesos de la política de ocupación total del dirigismo económico, para no pagar, una vez más, la eliminación de un paro temporal con la destrucción de la ordenación económica. Es perfectamente posible, sin embargo, practicar una política de coyuntura dentro de los límites señalados por las reglas del juego de la economía de mercado ${ }^{72}$.

Queda de esta forma en entredicho una política anticíclica que asuma como variable la ocupación, así como objetivos económicos directos $^{73}$.

A pesar de la compatibilidad declarada entre política social y mercado, conviene ver más de cerca cómo se articula ésta. Como se ha visto, dos han sido los aspectos de política social que se confrontan con el mercado: la ocupación y la distribución de la riqueza. La propuesta ordoliberal respecto a ambas cuestiones parte de la crítica radical a la intervención específica para estos objetivos. Tanto el empleo como la distribución, se confieren primariamente al mercado, de tal forma, que sólo su eficiente funcionamiento es la vía para su tratamiento.

El empleo es sin duda la cuestión que más críticas ha suscitado por la escuela ${ }^{74}$, estableciéndose una contradicción entre políticas de pleno empleo y mercado. La acción pública dirigida a la máxi-

71 Muller-Armack, A., "Las ordenaciones económicas desde el punto de vista social", op. cit.

72 Muller-Armack, A., "Las ordenaciones económicas desde el punto de vista social", op. cit.

73 REICH, R., Mercado y derecho, op. cit., págs. 45-46.

74 EUCKEN, W., "El problema político de la ordenación», op. cit. 
ma ocupación conlleva en su propuesta la sustitución de los mecanismos del mercado, por tanto, el resultado debe ser el abandono del pleno empleo como objetivo económico. En este sentido, la compatibilidad entre empleo y mercado debe ser la que establezca este último.

Algo similar ocurre con la distribución de la renta. De hecho, la caracterización de la economía de mercado exige que la política social sea un apósito residual, "la creación de una auténtica economía de mercado, a la que se añaden mejoras sociales" 75 . Se limitan las posibilidades de intervención, reduciendo el sistema de protección social, la intervención en los salarios y otras políticas sociales; de tal forma, las medidas adoptadas no interfieren en los mecanismos de funcionamiento del mercado. flustrativa, en este sentido, es

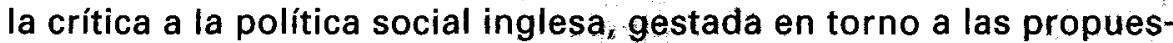
tas del tandem Beveridge-Keynes, a la que se achacan los efectos desnaturalizadores de la lógica interventora respecto al funcionamiento del mercado ${ }^{76}$.

También contribuye a relativizar el alcance de la dimensión social de la economía de mercado en la propuesta ordoliberal la crítica a la posición y función de los sindicatos, considerados como agentes limitadores - "monopolios bilaterales de empresarios y trabajadores" ${ }^{77}$ - de la competencia, de la cartelificación de la economía que dificulta el funcionamiento del mercado. En esa prioridad del mercado se expulsa de la constitución económica al elemento sustancial del trabajo y de su acción organizada, rompiendo con la conexión realizada en la doctrina socialdemócrata weimariana, entre integración del trabajo y Estado social.

Aunque la política económica de la República. Federal no se materializó en esos parámetros, resulta importante señalarlos como referencia a la que confrontar la propuesta del Estado regulador que se empieza a articular en la pasada década.

Ciertamente, esta propuesta de la "economía social de mercado" tiene su influencia en la doctrina europea, aunque necesariamente resulta adaptada a los condicionantes constitucionales. En

75 Muller-Armack, A., "Las ordenaciones económicas desde el punto de vista social"), op. cit.

36 Mullef-Armack, A., "Las ordenaciones...", op. cit. EUCKen, W., "El problema politico de la ordenación", op. cit.

77 Muller-Armack, A., "Las ordenaciones...", op. cit. 
torno al concepto de "economía mixta», usada también de forma intercambiable con el de "economía social de mercado" 78 se establece la primacía de los elementos privatistas del sistema que confinan a posiciones subalternas al elemento social y sus instrumentos de realización.

En la iuspublicística italiana son significativas las posiciones de Bognetti ${ }^{79}$, que encabeza un sector que en los años ochenta del pasado siglo inicia una revisión de las posiciones mayoritarias, la interpretación de la economía mixta, en el marco de la democracia social, le lleva a situar en el centro del modelo los elementos privatistas, propiedad e iniciativa privada que actúan como elementos correctores $y$ límite a posibles intervenciones; lo que define al modelo son los principios del mercado, la dimensión social resulta siempre subordinada ${ }^{80}$.

En sus últimas aportaciones se construye una identificación constitucional con su propuesta. "La Constitución, en efecto, ha acogido lo que es tradicionalmente el planteamiento privatista de la economía, que, interpretado de cierta forma, puede ser considerado absolutamente preeminente " ${ }^{81}$. Esta interpretación es asimismo declarada como la única congruente, no sólo con las transformaciones en curso, sino con las orientaciones impuestas por el ordenamiento comunitario ${ }^{82}$.

Igualmente, la doctrina española, especialmente la administrativista, ha construido un modelo de constitución económica basado en una reinterpretación de la economía mixta que deviene economía de mercado, a la que se subordinan el resto de los elementos ${ }^{83}$.

78 ARIÑo, G., Principios de Derecho público (modelo de Estado, gestión pública, regulación económica), Comares, Granada, 1999, pág. 128.

79 BogNeTtI, G., Costituzione economica e corte costituzionale, Giuffré, Milan, 1983.

80 BOGNETTI, G., Costituzione economica e corte costituzionale, op. cit.

81 BOGNETTI, G., Intervención en el workshop del observatorio "Giordano Dell'Amore" sobre "La costituzione economica», Milán, 29 de marzo 1996, en I" Federalismo fiscale. La costituzione economica, Giuffré, Milán, 1998, pág. 47.

82 BOGNETTI, G., «La costituzione economica tra ordenamiento nazionale e ordenamiento comunitario", en La costituzione economica, Ferrara, 11-12 octubre, 1991, Cedam, Padua, 1997, págs. 69-153.

83 Por todos, ver ARIÑo, G., Principios de Derecho público..., op. cit. 


\section{LA CONSTITUCIÓN ECONÓMICA DEL ESTADO SOCIAL}

La otra de las interpretaciones sustancialistas de la constitución económica sienta su base de partida en la forma de "Estado social", de la que derivan precisas consecuencias constitucionales, en la medida en que la cláusula de "Estado social" integrada constitucionalmente de forma explícita o implícita, forma parte del constitucionalismo de la II Postguerra mundial.

Ciertamente es difícil deducir una posición unitaria en la doctrina, aun reclamándose de este planteamiento metodológico, pero podríamos decir que dos son los puntos esenciales de coincidencia.

El primero consiste en reconocer a la forma de "Estado social" como la decisión constitucional básica que preside toda la Constitución económica. Por encima de las específicas disposiciones relativas a la actividad económica, la forma de Estado supone la referencia de conjunto que dota de coherencia e impone una relación de funcionalidad a las disposiciones específicas sobre la materia ${ }^{84}$.

Desde esta perspectiva, pierden centralidad expresiones como "economía mixta" y, por supuesto, la de "economía social de mercado", cuando se usan, indican, más que una capacidad de dirección interpretativa, la ruptura de la autonomía del mercado. La referencia primaria se coloca pues en el Estado social.

Sin embargo, ciertamente, el concepto de Estado social es un concepto polivalente, admitiendo una pluralidad de significados, por ello mismo conviene fijar las coincidencias fundamentales en las consecuencias que éste despliega sobre la Constitución económica. Podríamos decir, formulado de un modo todavía genérico, que la consecuencia fundamental, que constituye el segundo punto de coincidencia, es la aceptación de que el Estado social impone un "vínculo social» al sistema económico ${ }^{85}$,vínculo que permite constituirse tanto en fuente de definición, como en límite de las libertades económicas constitucionalmente reconocidas.

84 Spagnuolo Vigorita, V., L'iniziativa economica privata nel diritto pubblico, Jovena, Nápoles, 1959, págs. 52-3.

85 CANTARO, A., "El declive de la Constitución económica del Estado social», en El Constitucionalismo en la crisis del Estado social, UPV, Bilbao, 1997, págs. 153 yss. 
La doctrina italiana ${ }^{86}$ recoge una evolución en la configuración del sistema de sujecciones del privado y el mercado, impuesto por el Estado social, que materializan el vínculo social. En todo caso, hasta la década de los setenta del pasado siglo, la doctrina más significativa, desde distintas perspectivas, todas ligadas con la forma de Estado, construía la relación público-privado como un sistema fuerte, donde las potencialidades del Estado social permitían una incisividad interventora de los poderes públicos que afirmaba la primacía de la política en relación con la economía ${ }^{87}$.

En el período que va desde la aprobación de la constitución y que recorre la década de los cincuenta, el debate se centra precisamente en el grado de influencia de las prescripciones constitucionales directamente vinculadas al Estado social, sobre la propiedad y la iniciativa económica, en torno a la fórmula de libertades económicas funcionalizadas.

Los años sesenta presentan la constitución económica vinculada al debate sobre la planificación, nada extraño, si se tiene en cuenta que son los momentos de discusión y balance de una experiencia que en esos momentos alcanza una cierta generalización. Los años setenta evidencian un agotamiento de este argumento como polo definidor de la Constitución económica y la relación público-privado. Registra esta época una cierta recuperación del debate inicial. Los artículos 1,3 y 4 actúan como base de legitimación de una intervención que incide en la iniciativa privada, ésta sólo cobra sentido constitucional en el cuadro del gobierno público de la economía ${ }^{88}$ y sirve de base para el establecimiento de límites fuertes respecto a las libertades económicas privadas.

Es significativo que, mayoritariamente, la doctrina construye la constitución económica sobre la preeminencia normativa de los preceptos referidos a la forma de estado y el establecimiento de un vínculo fuerte del sistema económico, justo en los momentos de esplendor del Estado social. $145-70$.

86 Carl, P., Costituzione e attività economiche, Cedam, Padua, 1978, págs.

87 Galgano, F., "La libertà d'iniciativa economica privata nel sistema delle libertà costituzionali», en La Costituzione economica. Trattato di diritto comerciale e di diritto pubblico dell'economia, vol. I, Cedam, Padua, 1977, págs. 511-30.

88 Galgano, F., Introducción a La Costituzione economica, op. cit. 


\subsection{La determinación del vínculo social}

En los momentos sucesivos a la aprobación de la Constitución italiana, la constitución económica está condicionada por la caracterización de la forma de Estado, de la que, como hemos dicho, se deriva la funcionalización de las libertades económicas a las exigencias del Estado social. La definición de éste, a pesar del debate en torno a la propia fórmula ${ }^{89}$, se realiza en base al trabajo (arts. 1 y 4). La iuspublicistica más relevante (Giannini y Mortati) sienta las bases de una interpretación constitucional que afectará directamente a la constitución económica, sobre la centralidad del trabajo.

La noción de Estado pluriclase, cuya construcción se inicia ya en el proceso constituyente ${ }^{90}$ preside las consideraciones constitucionales de Giannini y ésta es concebida como proceso de integración del trabajo en su expresión política y social. La Constitución del $\mathbf{4 7}$ se caracteriza como constitución convencional pluriclase, que interioriza en un sistema de garantías, la integración del trabajo ${ }^{91}$.

Concebida la constitución como sistema de garantías que materializa el nuevo status del trabajo, importancia determinante tienen aquéllas que se refieren a la coparticipación en el «indirizzo politico sustancial”92. Aunque el grupo de garantías incluido por Giannini es heterogéneo, contiene aquéllas que redefinen el estatus jurídico de las libertades económicas, en su función de limitación de los privilegios de las clases sobreprotegidas. La funcionalización de la propiedad y la iniciativa privada, así como las referencias a la programación, se inscriben en el marco del reequilibrio de poder constitucionalmente reconocido. Por ello, la propia noción de forma de Estado impone un vínculo fuerte del sistema económico a través de la funcionalización y limitación de las libertades del privado, consideraciones que, en lo sustancial, se mantienen posteriormente.

89 GIANNINI, M. S., "Stato sociale: una nozione inutile", en Scritti in onore di C. Mortati, vol. I, Giuffré, Milan, 1977, págs. 139 y ss.

90 GIANNINI, M. S., "Relazione preliminare sul rapporto tra lo stato e cittadini attinenti all'eguaglianza e alla solidarietà sociale", en Alle origini della costituzione italiana, II Mulino, Bolonia, págs. 677 y ss.

91 GIANNINI, M. S., "La rilevanza costituzionale del lavoro", op. cit.

92 GIANNINI, M. S., "La rilevanza costituzionales del lavoro", op. cit. 
Más explícita, tanto en su afirmación del "principio laborista» ${ }^{93}$ como en la funcionalización de los institutos económicos privatísticos y en la legitimidad de una intervención altamente incisiva de los poderes públicos en el sistema económico es la propuesta de Mortati.

En torno a los arts. 1, 3 y 4 de la Constitución italiana, este autor afirma la recepción de la forma de Estado social en la constitución y que éste debe ser primariamente caracterizado por la centralidad del trabajo. Ello se manifiesta en su papel dirigido a la superación de la situación de subalternidad de la clase trabajadora y en el contraste con otras formas de Estado, tanto la liberal, como la socialista ${ }^{94}$. Así pues; es definido, también por Mortati, el Estado social como proceso de integración del trabajo.

Lo especialmente relevante, que incidirá en la consideración constitucional de las relaciones económicas, es la relevancia otorgada al art. 4 y al papel del pleno empleo, requisito básico de construcción del nuevo Estado constitucionalmente sancionado. Tanto es así que la ocupación se constituye como parámetro legitimador del sistema interventor y asume el papel de núcleo conformador de los contenidos de la libertad económica ${ }^{95}$. Así, el pleno empleo, como mandato impuesto por el artículo 4 impondría un conjunto de obligaciones que comprometen a los poderes públicos y privados ${ }^{96}$.

Al legislador le impone tanto obligaciones de hacer (dirigir sus intervenciones a la consecución del máximo empleo) como de no hacer (no derogar normas existentes que se dirijan a facilitar la ocupación sin sustituirlas por otras de la misma finalidad). A la administración, la obligación de ejercitar sus poderes de forma que no se obstaculice la creación de empleo, sino que se favorezca. En las relaciones con los sujetos privados, la obligación de utilizar su autonomía en el campo de las relaciones productivas con respecto al fin de la ocupación ${ }^{97}$.

93 Mortati, C., Istituzioni di diritto pubblico, tomo I, Cedam, Padua, 1969, págs. $147-8$.

94 MORTATI, C., "ll lavoro nella costituzione", en I/ diritto del lavoro, Giuffré, Milán, 1954, págs. 149 y ss.

95 MORTATI, C., "Iniziativa privata e imponibile di mano d'opera", en Giurisprudenza costituzionale, 1958, págs. 1190 y ss.

96 MORTATI, C., "ll diritto al lavoro secondo la costituzione delle Repubblica”, en Raccolta di scritti, vol. III, Giuffré, Milán, 1972, págs. 142 y ss.

97 Mortatı, C., "ll lavoro nella Costituzione", op. cit. 
Sobre la base de esta vinculación fuerte del sistema económico y el papel público en la actuación del pleno empleo, al que se reconducen tanto las alusiones constitucionales a la utilidad, función social, o el interés general, como aquellas otras directamente conectadas al modelo de Estado (art. 3.2), del que resultan precondición para su realización, construye Mortati una caracterización de las libertades económicas.

Carli se refiere a la funcionalización de la iniciativa privada al pleno empleo ${ }^{98}$ como uno de los debates doctrinales fundamentales en la conformación de la constitución económica durante los años cincuenta.

La fórmula "funcionalización de los derechos económicos" implica una definición del contenido del derecho que se realiza desde los fines que debe satisfacer y va más allá de la concepción de límite del derecho otorgado a las cláusulas de "interés socialn.

Este debate gira en torno a las posiciones de Mortati articuladas en base al artículo 4 (derecho al trabajo), que tienen su momento más álgido en las posiciones mantenidas en torno a la cuestión del «imponibile di mano d'opera", es decir, a la posibilidad de imponer obligaciones positivas a la actividad empresarial, referida, en este caso al empleo ${ }^{99}$.

Sea como fuere, el propio debate ilustra la relación público-privado que se ordena en una relación de subordinación que afecta, cuando menos, a la definición de la iniciativa y propiedad privada.

Pero en esos momentos, las posiciones doctrinales que concebían las normas constitucionales que incorporaban la forma de Estado social al texto fundamental, como decisiones de fondo, que definen la Constitución económica están representadas por un amplio espectro doctrinal 100 .

Las prescripciones constitucionales referentes al trabajo, los Derechos sociales, la iniciativa privada y la propiedad, ambas susceptibles de vinculación positiva a la utilidad social, permiten una

98 CARLI, P., Costituzione e attività economiche, op. cit., págs. 145-55.

99 MORTATI, C., Iniziativa privata e imponibile di mano d'opera, op. cit.

100 Spagnuolo Vigorita, V., L'iniciativa economica privata nel diritto pubblico, op. cit., págs. $49-51$. 
calificación de la constitución económica en contraste con otras que, como mínimo, podrían caracterizarse como no individualista o social ${ }^{101}$.

Esta se define en contraposición a la constitución económica de los Estados democráticos burgueses y excluye un sistema que otorgue la prevalencia al interés privado.

Las consecuencias que se extraen implican una fuerte subordinación del privado, que se tradujo en una incisiva intervención estatal e incluso en una economía ampliamente programada en actuación del vínculo social que se identifica, fundamentalmente, con el pleno empleo ${ }^{102}$. La intervención económica se configura como deber público, conformándose como regla frente a la excepción que significa la automía del mercado. Por ello, el papel de los artículos 41 y 42 (iniciativa privada y propiedad) es más el de garantía frente a la obligación general impuesta por la forma de Estado, que de definición de la Constitución económica ${ }^{103}$.

\subsection{El gobierno de la economía}

Si en el primer momento del debate constitucional éste giró en torno a la funcionalización de las libertades económicas, construyendo una concepción fuerte de la vinculación social del sistema económico, el momento siguiente viene representado por la planificación, representa un cambio cualitativo, en la medida en que trasciende del análisis de las disposiciones constitucionales, aún vinculadas al del Estado social, para pasar al gobierno global de la economía.

La planificación como gobierno global de la economía supone la ruptura de la constitución económica liberal ${ }^{104}$ y la vinculación con el Estado pluriclase, en cuyo marco cobra sentido ${ }^{105}$.

101 Spagnuolo Vigorita, V., L'íniciativa economica privata nel diritto pubblico, op. cit., págs. 62-4.

102 Spagnuolo Vigorita, V., op. cit., págs. 104-113.

103 Spagnuolo Vigorita, V., op. cit., pág. 114; Balladore Pallieri, G., Giuffré, Milán, 1953, pág. 352.

104 Predieri, A., Pianificazione e Costituzione, Ed. Communità, Milán, 1963. págs. 21-29:

105. GianniNI, M. S., Diritto pubblico dell'economia, II Mulino, Bolonia, 1977, págs. 34; también, Il pubblico potere. Stati e amministrazioni pubbliche, II Mulino, Bolonia, 1986, págs. 130-4. 
La superación de la constitución económica liberal permite la caracterización de la Constitución económica del Estado social como economía mixta, rasgo este que se debe al elemento de la Constitución material del Estado ${ }^{106}$. En este caso, sin embargo, economía mixta no significa, como se ha pretendido, la convivencia de iniciativa pública y privada bajo la prevalencia del mercado, sino la subsistencia del ámbito privado en posición de subordinación. "Esta constitución económica es absorbida y formalizada en sus lineamientos de sistema innegablemente mixto... caracterizada por una regulación, o más precisamente, de una dirección centralizada o planificada macroeconómicamente asumida por los órganos de la constitución formal... Esta regulación asegura funcionalmente la conexión entre Estado y organización económica, instrumentada de forma de asegurar la preeminencia del Estado para dirigir y modificar la organización económica»" ${ }^{107}$.

La planificación, como expresión de la dirección pública del sistema económico que evidencia la prevalencia de la política derivada de la forma de Estado social no concebida reductivamente ${ }^{108}$, plantea como problemas tanto el carácter de la misma, como su vinculación respecto a los agentes privados, sancionando su subordinación.

El traslado del acento a la planificación del primer planteamiento, que establecía la relación público-privado deducido de los preceptos que eran expresión constitucional de la forma de Estado, viene justificado por la propia evolución de la situación italiana. Los años sesenta registran una demanda de intervención general del sistema económico que sanciona el fin del período de reconstrucción y el agotamiento de las políticas de imposición autoritaria que basaban la competitividad en los bajos salarios ${ }^{109}$. El impulso salarial, el reforzamiento sindical y la necesidad de responder a nuevas condiciones de competencia definía el marco de los debates sobre la planificación. «El cambio registrado, en suma, se resolvía en el fondo, en una demanda de gobierno, de una dirección estatal, que programase el desarrollo de los diversos sectores programando sobre todo las demandas de los mismos operadores públicos, que incentivase no los rústicos, sino la

\footnotetext{
106 Predieri, A., Pianificazione e Costituzione, op. cit., pág. 35.

107 Predieri, A., Pianificazione e Costituzione, op. cit., pág. 38.

108 Predieri, A., Pianificazione e Costituzione, op. cit., pág. 48.

109 АмAто, G., "ll governo dell'economia: II modello politico", en Trattato di diritto commerciale e di diritto pubblico dell'economia. Vol. I, La Costituzione economica, Cedam, Padua, 1977, págs. 209-33.
} 
investigación, que concurriese a la ampliación de nuestra ventaja productiva y a la modernización tecnológica de los sectores retrasados: cosas completamente extrañas al viejo modo de gobierno» ${ }^{110}$.

En estas condiciones, pues, se abre un nuevo nivel de reflexión sobre la constitución económica, preludio a una experiencia que, sin embargo, tendrá poco alcance.

Como hemos comentado, la planificación plantea doctrinalmente dos problemas, el primero de ellos, su vinculación con las nuevas funciones del Estado en la economía, es decir, el deber público de planificar como respuesta a las previsiones interventoras constitucionales y a las funciones que el poder público absuelve en el Estado social.

Aunque las posiciones son encontradas, es importante señalar que la doctrina considera la planificación como un deber constitucional del Estado, impuesto por las cláusulas reconducibles a la forma de Estado.

La vinculación de los planes exige, sin embargo, una construcción más compleja. Esta cuestión no es sino la extrapolación al ámbito del gobierno global del sistema económico de los vínculos al poder económico privado. Planificación, de esta forma, significa, prima facie, restricción de la capacidad de decisión empresarial111, expresión de una general subordinación del privado al vínculo social del sistema económico. Por ello, el artículo 41.3 de la Constitución italiana es enmarcado en la forma de Estado.

Aunque la construcción de Predieri es técnicamente complicada, vinculando el plan a su instrumentación normativa, reserva de ley y a la eficacia de este instrumento ${ }^{112}$, la conclusión inevitable es la afirmación del carácter vinculante del plan. Escapando a la diferenciación entre planificación imperativa e indicativa establece su carácter vinculante, que se traduce en la capacidad de imponer obligaciones positivas a los agentes privados.

Igualmente importante en este debate sobre la programaciónplanificación es el planteamiento que Predieri realiza sobre la elasticidad constitucional referida precisamente a los instrumentos interventores, incluido el gobierno general de la economía, flexibilidad que no

110 Amato, G., "ll governo dell'economia: Il modello politico", op. cit.
111 Predieri, A., Pianificazione e costituzione, op. cit., pág. 53.
112 PredienI, A., Pianificazione e costituzione, op. cit., págs. 111-2, 214-5. 
debe separarse de la constitución material económica del Estado social. Esta cuestión permite abordar desde la perspectiva de la forma de Estado cuestiones que, en parte de la literatura, fundamentaban, de hecho, una constitución económica, que recuperaba la lógica liberal; nos referimos a la neutralidad constitucional en la materia o a la canalización de fórmulas como "economía mixta». También permite situar la compatibilidad entre las distintas fundamentaciones de la intervención pública ${ }^{113}$.

Si el debate sobre el gobierno de la economía giró en los años sesenta alrededor de la planificación, la limítación de las experiencias de estos años desplazaron la fundamentación de esta dirección global a una concepción de la democracia vinculada al Estado pluriclase.

Dentro del marco definido por el modo de producción capitalista, consagrado por la constitución italiana (respecto de la forma jurídico-económica de la empresa) ${ }^{114}$, las libertades económicas significan la garantía de un espacio de concurrencia dentro del ámbito económico, cuya definición corresponde al Estado.

La legitimación de la intervención pública "sobre la economía»"115 reside en la definición material de la libertad y la igualdad y en una concepción de la participación política en clave de integración de clase.

De esta forma, se produce, no sólo una superación de la vieja división liberal entre política y economía y la mixtificación de estos espacios, sino la potencial ampliación de la política representada por la posibilidad de la deseconomización de los espacios del lucro prịvado cuando éstos dificultan la consecución de los principios señalados. Esto es el significado de la primacía de la política que identifica la relación entre ésta y la economía en el Estado social.

La forma como se plasma esta relación depende de las relaciones de clase que en cada momento se instauren. Se traslada así el acento de la constitución económica a elementos antes menos explicitos, aquellos derivados de la constitucionalización de la subjetivización política del trabajo, que se integra plenamente en este ámbito116.

113 DE CABO, C., La crisis del Estado social, PPU, Barcelona, 1986, págs. 36.

114 Galgano, F., Introduzione a la Costituzione economica. Tratato di diritto commerciale e di diritto pubblico dell'economia, vol. I, op. cit., págs. 3-136.

115 Galgano, F., Introduzione a la Costituzione economica, op. cit.

116 GALGANO, F., "La libertà d'iniciativa...". Tratato di diritto commerciale e di diritto pubblico dell'economia, vol. l, op. cit. 


\subsection{Constitución económica y Constitución material del Estado social}

La relativa variación de los elementos caracterizantes de la constitución económica del Estado social dependen, como puede observarse, de la evolución del conflicto y de las relaciones entre los protagonistas (constitucionalizados) del mismo.

La centralidad sindical de los años setenta en Italia explica estas consideraciones realizadas respecto a la evolución del debate ${ }^{117}$. Sin embargo, esta secuencia evolutiva confirma las relaciones entre la constitución económica y la forma de Estado, que es su fuente de definición. Por ello mismo, para cerrar el círculo iniciado en el período postconstituyente conviene retomar la Constitución material, concepto que en la formulación mortatiana se vincula directamente con la forma de Estado ${ }^{118}$, como elemento delimitador de la Constitución económica. Esta es la propuesta del epílogo doctrinal sobre el Estado social.

Ciertamente, el Estado social no puede concebirse en términos exclusivamente económicos, ni políticos ${ }^{119}$, de la misma forma que sus componentes aluden a la "doble dimensión conflictualista y funcionalista» ${ }^{120}$ en su explicación, lo que determina su carácter de compromiso inestable 121 , sobre el que se teoriza la elasticidad constitucional de su expresión jurídica ${ }^{122}$.

Si el Estado social puede concebirse como el proceso de integración del trabajo, asumiendo el contenido de la propuesta de Giannini, ésta se produce en un doble plano: el político y el económico. La intima conexión entre estos planos, fruto de la ampliación de la esfera de la política, hace que ambas definan las condiciones materiales de esta forma de Estado.

117 Romagnol, U., "ll sistema economico nella costituzione", en La Costituzione economica. Trattato di diritto commerciali..., op. cit., págs. 139-84.

118 MoRTATI, C., Le forme di governo, Cedam, Padua, 1973, pág. 39.

119 Barcellona, P., y Cantaro, A., La sinistra e lo Stato sociale, Ed. Riuniti, Roma, 1984. págs. 45; García Herrera, M. A., "Los antecedentes teóricos del Estado social", en El bienestar de la cultura, UPV/EHU, Bilbao, 2000, págs. 163-93. págs. 28-30.

120 De Cabo MARTín, C., La crisis del Estado social, PPU, Barcelona, 1986, pág. 37.

121 De Cabo Martín, C., La crisis del Estado social, PPU, Barcelona, 1986,

122 Predieri, A., Pianificazione e costituzione, op. cit., pág. 214. 
La integración política se expresa constitucionalmente en el reconocimiento de la subjetividad política del trabajo. Este reconocimiento institucionaliza el conflicto y preserva el status del trabajo en el desarrollo del mismo. Es la base política que permite actuar el conflicto dentro de los límites definidos en el compromiso fundador del Estado social. Esta es la significación del debate acerca de la naturaleza del sindicato $y$ de la huelga política, especialmente en la jurisprudencia constitucional y la doctrina italiana. La evolución del conflicto, tutelado institucionalmente, define el resultado coyuntural de la relación entre sus protagonistas y se traduce en el ordenamiento infraconstitucional, expresando la flexibilidad constitucional del Estado social.

La integración económica define, en torno al compromiso keynesiano, las bases materiales del status de los sujetos protagonistas del constitucionalismo social. Los mecanismos interventores y el vínculo social del Estado, que imponen obligaciones a los poderes públicos, dentro de los límites constitutivos del Estado social, preservan las bases del equilibrio relacional entre el capital y el trabajo.

El pleno empleo se constituye en vínculo político-económico para el Estado en cuanto base material de la definición del conflicto. Ciertamente, la ocupación no es sólo la base material del status del trabajo, sino el resultado de la ecuación keynesiana, punto de encuentro del conflicto.

Los Derechos sociales expresan el nivel de garantía política de la integración económica ${ }^{123}$. Reflejan en su estructura, al igual que el resto de los mecanismos de intervención económica, la doble dimensión de esta forma de Estado, la garantista y la de disponibilidad confiada al desarrollo del conflicto.

Esta naturaleza compleja de los Derechos sociales es la causa de los problemas en la definición de su status jurídico. La dimensión disponible de los mismos ${ }^{124}$ no puede empañar la de garantía que contribuye a soportar el doble compromiso de integración política y económica del trabajo ${ }^{125}$.

123 García HerRera, M. A., "Antecedentes teóricos del estado social: de los pobres al obreron, en Estudios de Teoría del Estado y Derecho constitucional en honor de Pablo Lucas Verdú, tomo I, U. Complutense, Madrid, 2000, págs. 265-291.

124 Barcellona, P., "Diritti sociali e corte costituzionale", en Rivista Giuridica del Lavoro e della Presidenza sociale, 1994, n. ${ }^{\circ} 3$, págs. 325-31.

125 BALDASSARRE, A., Voz "Diritti sociali", en Enciclopedia Giuridica trecani, vol. XI, Roma, 1989. págs. 1-34; LUCIANI, M., "ll diritto costituzionale della salute», 
El problema de la constitución económica del Estado social estriba en la definición e interrelación entre el momento conflictual y el garantista, es decir, en la determinación del núcleo social del Estado en su intervención económica y en la protección.

El vínculo social tiene que ver con el reconocimiento de las "bases materiales de la subjetividad" de las partes del conflicto social ${ }^{126}$, que definen la constitución material del Estado social. Flexibilidad constitucional y vínculo social definen los momentos dinámico y garantista del Estado social y determinan su Constitución económica.

El momento conflictual, la dinámica de la acción de las fuerzas sociales, no puede comprometer esas bases materiales sin las que no es reconocible el pacto de integración.

Lo que denominamos el vínculo social de la constitución económica del Estado social no es sino un mandato de preservación del fundamento material de la integración. Un límite al conflicto que resulta paralelo al impuesto al trabajo de no modificación de las bases del capitalismo, la formulación constitucional del «control político-estatal de los resultados espontáneos del conflicto, con el fin de compensar las desigualdades económico-sociales, sin limitaciones cuantitativas, en la extensión de la intervención pública ${ }^{127}$.

Implica, por tanto, una obligación de compatibilidad, que expresaba la ecuación keynesiana, entre mercado y soporte material del sujeto trabajo, que impide interpretaciones que reclaman la primacía o unilateralidad del mercado ${ }^{128}$ o la definición de la intervención y tutela social desde el mismo.

La Constitución económica se expresa como un sistema de vínculos o límites que establecen el campo de compromiso. Los mecanismos de intervención son funcionales a la materialización de éste y

en Diritto e società, 1980 , n. $^{\circ} 4$, págs. 769-811; Garcí Herrera, M. A., y Maestro BUELGA, G., Marginación, Estado social y prestaciones autonómicas, CEDECS, Barcelona, 1999, págs. 42-53.

126 Barcellona, P., y Cantaro, A., "Estado social entre crisis y reestructuración", en Derecho $y$ economía en el Estado social, Tecnos, Madrid, 1988, págs. 49-70. pág. 46.

127 Barcellona, P., y Cantaro, A., La sinistra e lo stato sociale, op. cit., 128 ARIÑo, G., Principios de Derecho Público, op. cit. 
la intensidad de su aplicación dependen del resultado coyuntural del conflicto.

La ruptura del vínculo social que, como hemos dicho, establecía la compatibilidad entre mercado y garantía de la integración del trabajo, marca el fin de la Constitución económica del Estado social. La definición de la intervención social y económica desde el mercado ${ }^{129}$ establece una nueva centralidad, que supone la contradicción entre mercado e integración y sienta las bases de la nueva Constitución económica postfordista.

Las bases sobre las que se organiza la nueva Constitución económica, que no son otras que la desaparíción de los vínculos impuestos al sistema económico por el Estado social, supone el punto de coincidencia con las transformaciones impuestas en el proceso de globalización económica.

\section{LA GLOBALIZACIÓN ECONÓMICA, FUNDAMENTO LEGITIMADOR DE LA NUEVA CONSTITUCIÓN ECONÓMICA}

A pesar de que la globalización hace ya algún tiempo que se ha convertido en elemento recurrente en la literatura sobre el Estado y sobre las transformaciones del sistema económico, todavía, la primera de las cuestiones a que obliga cualquier pronunciamiento sobre el tema, es definir su alcance. El debate sobre su existencia como elemento novedoso, impulsor de transformaciones que inevitablemente condicionan el comportamiento de los viejos protagonistas del sistema político y económico, sigue existiendo ${ }^{130}$. Posiblemente, la discusión sobre globalización sí o no, no es sino el intento de ocultar que los frutos y las novedades que parecen imponer los nuevos comportamientos económicos del Estado son consecuencia de la crisis del Estado social y de la estrategia de configuración de la nueva forma de Estado, definida en torno al postfordismo.

129 BaRCellona, P., "Globalización e crisi dello stato sociale", en Contro Maastricht, Punto Rosso, Roma, 1997, págs. 82-101. DE LA QUADRA, T., "Constitución y modelo económico liberalizador", en Cuadernos de Derecho público 2000, n. 9 , págs. 27-47.

130 PIzzorno, A., "Natura della disuguaglianza, potere politico e potere privato nella società in via di globalizzazione», en Stato e mercato 2001, n. ${ }^{\circ} 62$, págs. 201-27. 
Desde esta perspectiva, la globalización más que explicar nuevos procesos, aunque obviamente incorpora elementos novedosos, cumple funciones de legitimación, es decir, de justificación de las estrategias de definición del postfordismo. De esta manera, este último es el determinante para comprender el papel otorgado al proceso globalizador ${ }^{131}$, aunque es preciso reconocer que ambas dimensiones no son oponibles, sino que convergen en el proceso de desvinculación del sistema de sujeciones impuesto por el Estado social. Postfordismo y globalización son, pues, procesos concurrentes $y$, a menudo, indisociables.

La mayor erosión del concepto de constitución económica, gestado en el proceso de construcción del Estado social, viene, precisamente, de los efectos que se predican en relación al Estado por el proceso de globalización. La pérdida de la capacidad de decisión política, en el ámbito económico, del Estado, impuesta por la globalización imposibilitaría, en gran medida, una reconstrucción de las relaciones Estado-economía, presididas ahora por una retirada del ámbito de la política y la generalización de imperativos deducidos de un nuevo naturalismo económico que expulsa a la política de los espacios de decisión del mercado ${ }^{132}$.

El «Estado impotente» 133 quebraría la precondición para la definición pública del funcionamiento del sistema económico, sólo sobreviviría conceptualmente la Constitución económica al precio de la subordinación pública, consecuencia de la nueva relación entre los espacios de la política y la economía.

Sin embargo, para sentar las bases de acercamiento a la nueva constitución económica, nos parece más útil que el debate sobre el debilitamiento del Estado, un repaso a la construcción del proceso globalizador que ilustra, en nuestra opinión, su carácter ideológico. La globalización adquiere, ante las evidencias que aporta este proceso, la dimensión de proyecto político ${ }^{134}$ o mejor, como una estrategia de acu-

131 BARCELLONA, P., "Globalizzazione e crisi dello stato sociale», op. cit.

132 IRTI, N., "Diritto e mercato" en /l debatito sull'ordine giuridico del mercato, Laterza, Bari, 1999, págs. VII-XX.

133 WeISS, L., "Globalization and the mythe of the powerless state", en New Left Review, 1997, n. ${ }^{\circ} 225$, págs. 3-27.

134 Barcellona, P., Quale politica per il terzo millenio?, Ed. Dedalo, Bari, 2000, págs. 126-8. 
mulación capitalista en la nueva fase postfordista ${ }^{135}$ tendente a imponer la "organización capitalista de la sociedad y la política» ${ }^{136}$.

Este acercamiento a la globalización, por otra parte, nos parece el más clarificador para determinar su naturaleza. Como hemos dicho, el debate acerca del debilitamiento del Estado es engañoso, a pesar de ser el elemento más destacado de la literatura sobre la cuestión ${ }^{137}$ que remite al problema de la refundación de la democracia138. A trasladar la perspectiva de análisis contribuye el hecho de que los protagonistas del proceso de globalización no son tanto las dinámicas económicas autosuficientes, sino el sujeto Estado ${ }^{139}$, lo que obliga a huir de la simplificación de la ecuación globalización - desterritorialización económica - pérdida de poder del Estado.

Igualmente, la multiplicidad de intentos de definir el propio fenómeno, que perdura una vez consolidados los procesos y tendencias que impulsaba, indican que las manifestaciones externas más llamativas, que pretenden identificar la naturaleza de la globalización, deben ser situadas en el contexto de la forma de Estado, del tránsito al Estado postfordista. Más aún, si se entiende que muchos de sus rasgos no son novedades introducidas por esta fase del desarrollo capitalista y que la dimensión tecnológica, por sí misma, resulta insuficiente para caracterizar este proceso.

La necesidad de huir del determinismo naturalista en las relaciones Estado-economía tienen un soporte casi incontestable en el proceso histórico de configuración del sistema económico capitalista desde el fin del capitalismo concurrencial.

En su propuesta de búsqueda de una forma de cierre político a las aperturas que el sistema económico produce como efecto de la globalización, Habermas toma como referencia las consideraciones de

135 JESSOP, B., "Reflexiones sobre la ilógica de la globalización», Zona abierta, n. ${ }^{\circ}$ 92/93, 2000, págs. 95-12.

136 Barcellona, P., Quale politica per il terzo millenio?, op. cit., pág. 127.

137 HELD, D., Democracy and the global order. From the modern state to cosmopolitan governance, Polity Press, Cambridge, 1995. OHMAE, K., La fine dello stato nazione, Baldwein \& Costaoldi, Milán, 1991. HiRST, P., y THOMPSON, G., Globalization in question, Polity Press, Cambridge, 1996. Últimamente, desde otra perspectiva, HARD, M., y NEGRI, A., Imperio, Paidós, Barcelona, 2002.

138 Habermas, J., La costellazione postnazionale, Feltrinelli, Milán, 2000. Barcellona, P., Quale politica per il terzo millenio?, op. cit.

139 KAPSTEIN, E. B., Governing the global economy. International finance and the state, Harvard, U.P. Cambridge y London, 1994. 
Polanyi ${ }^{140}$. No sólo Polanyi propone una fórmula política de control de los efectos sociales del desorden del mercado, que luego se materializará en la construcción del Estado social, sino que la reconstrucción de los avatares históricos del liberalismo y del sistema económico internacional esclarece el papel del Estado en su determinación ${ }^{141}$. Aquello que importa recordar es que incluso el sistema de mercados libres en la economia, ya internacionalizada, del XIX y principios del siglo $X X$ fue un producto público, del Estado y del sistema de hegemonía internacional establecido en torno a la Inglaterra imperial. El mercado como construcción pública resulta inexistente sin su diseño institucional y el mantenimiento de las condiciones de su desarrollo. Convenimos con Irti que no hay mercado, sino mercados, es decir, aquellos frutos de la decisión política que los instaura y define ${ }^{142}$. El mercado es, pues, una institución política y por ello, instaura relaciones de dependencia respecto del Estado. Las transformaciones en la relación entre mercado y derecho ${ }^{143}$ no ensombrecen esta afirmación, sino que constituyen la manifestación de una nueva articulación fruto de la decisión adoptada en la instancia política.

La construcción de las bases económicas, esencialmente el diseño del sistema financiero internacional, de la intervención estatal en la economía durante la construcción y desarrollo del Estado social esclarece las consideraciones realizadas. Sin el acuerdo político entre Estados, la precondición de la autonomía estatal en el gobierno económico no hubiera existido, salvo la solución autárquica de un nacionalismo económico ${ }^{144}$ carente de sentido.

Curiosamente, al menos desde un análisis de historia económica, el keynesianismo político económico del Estado social, la autonomía en la política económica del Estado es una respuesta a una globalización ingobernada, generalizada en los comienzos del siglo XX y

140 Habermas, J., La costellazione postnazionale, op. cit., págs. 64-7.

141 PolANYI, K., La gran transformación, Ed. La Piqueta, Madrid, 1989, págs.

228-32.

142 IRTI, N., "L'ordine giuridico del mercato", en L'ordine giuridico del mercato, Laterza, Bari, 1998, págs. 3-64.

143 Ferrarese, "Las instituciones jurídicas de la globalización", en Jueces para la Democracia, n. ${ }^{\circ} 42,2001$, págs. 33-9. También Le Istituzioni della globalizzazione, II Mulino, Bolonia, 2000, págs. 110 y ss.

29-30.

144 ComBA, A., // neoliberismo internazionale, Giuffré, Milán, 1995, págs. 
decidida, o por lo menos favorecida por los Estados ${ }^{145}$. En la nueva conformación el sistema económico internacional, la configuración política del «liberalismo dirigido» ${ }^{146}$ es por tanto una decisión de gobierno de la globalización, entre cuyos elementos, como objetivos perseguidos, estaban la instauración de un ámbito de autonomía económica estatal, no determinada por el contexto internacional, sino favorecido y, en este marco, la creación y desarrollo de los Estados de bienestar europeos ${ }^{147}$. Estas consideraciones constituyen en la literatura económica un lugar común, a menudo olvidado en la producción sobre la globalización. Es un hecho reconocido la relación íntima entre los acuerdos de Bretton Woods y la creación de los Estados occidentales europeos de la postguerra ${ }^{148}$.

Si se admite este enfoque, necesariamente tiene que replantearse tanto la caracterización de la globalización, como las relaciones entre política y economía derivadas de ésta.

La globalización pues, debe entenderse como decisión política y como tal, se debe confrontar con el Estado social, de ahi nuestra adhesión a las caracterizaciones de ésta como proyecto político o, si se quiere, como estrategia de acumulación.

\subsection{La estrategia de la globalización}

Desde las consideraciones antes apuntadas, las dificultades descritas en orden a caracterizar la globalización pueden superarse si las tendencias globalizadoras se inscriben en la superación de las contradicciones que el proceso de acumulación capitalista había establecido en la fase final del fordismo. La globalización se manifiesta así como una estrategia de acumulación ${ }^{149}$, más específicamente, como la estrategia de acumulación de la fase postfordista ${ }^{150}$.

145 KeOHAME, R., "La economía política mundial y la crisis del liberalismo dirigido", en Orden y conflicto en el capitalismo contemporáneo, Ministerio de Trabajo y S. S., Madrid, 1991, págs. 33-64.

146 RUGGIE, J. G., "International regimes, transactions, and change: embedded liberalism in the postwar economic order», en International organization, 1982, n. ${ }^{\circ} 36$, págs. $379-415$.

147 IKEMBERRY, J. G., "Rethinking the origins of american hegemony", en Political Science Quaterly, 1989, vol. 104, págs. 375-400.

148 Keohame, R., "La economia política mundial...", op. cit.; RugGIE, J. G., "International regimes, transactions, and change...", op. cit.

149 JESSOP, B., "Reflexiones sobre la (i)lógica de la globalización», op. cit

150 JeSSOP, B., «Reflexiones sobre la (i)lógica de la globalización», op. cit. 
En este cuadro pueden insertarse las tendencias en acto, cuya característica fundamental es confrontarse con el modelo generalizado tras la instauración del Estado social.

Cuando se intenta distinguir entre los procesos de internacionalización económica anteriores a la Primera Guerra Mundial, ejemplo de las tendencias expansivas de la dinámica capitalista, y la globalización actual, el acento se pone, no tanto en los datos cuantitativos del intercambio, cuanto en la reacción frente a las novedades que incorpora el Estado social al gobierno del proceso económico. Respecto al período que llega hasta 1913, los factores novedosos se sitúan, por una parte, en el carácter otorgado al salario en la definición de las condiciones de competencia y, por otra, a la desvinculación de las sujecciones impuestas al mercado de capitales.

El keynesianismo económico y la aparición de los sistemas de protección social nacionales provocan que el salario social adquiera una nueva dimensión, se configura como «coste internacional de producción " ${ }^{151}$, influyendo en las condiciones de competencia.

Por esto resulta engañoso contrastar, para medir la intensidad del fenómeno globalizador, la situación actual con la experiencia pasada. La globalización se contrapone al sistema de sujecciones políticas del Estado social, así como a las relaciones entre los sujetos de conflicto social ${ }^{152}$.

De esta manera resulta erróneo contraponer globalización a Estado y deducir de ello la pérdida del poder estatal en el control de la economía. Esto sólo es cierto si los términos de la contradicción no se establecen con el Estado, sin más, sino con una forma de Estado determinada. Los cambios en el escenario internacional respecto a los mercados financieros son inscribibles en esta estrategia de la acumulación, a la que no son ajenos los Estados, protagonistas políticos del nuevo diseño del mercado de capitales.

"Por ello el salario, tanto el individual, como el social, comenzó a ser entendido cada vez más como un coste de producción interna-

151 JESSOP, B., «Reflexiones sobre la (i)lógica de la globalización», op. cit.

152 JeSSOP, B., "Reflexiones sobre la (i)lógica de la globalización», op. cit. Tambiem DoGLIANI, M., "Deve la politica democratica avere una risorsa di potere separata", en Dallo Stato monoclasse alla globalizzazione, Giuffrè, Milán, 2000, págs. 61-72. 
cional ${ }^{153}$ y menos como una fuente de demanda nacional y el dinero empezó a circular como divisa internacional debilitando ciertamente la gestión económica keynesiana de la demanda en el ámbito nacional. Este cambio en el principal aspecto contradictorio de la forma del dinero está estrechamente relacionado con la tendencia de la dinámica del capital industrial a estar subordinado a la lógica de hipermovilidad del capital financiero" ${ }^{154}$.

Que la contradicción que impone la globalización no es entre economía mundial y Estado lo demuestran dos aspectos del proceso globalizador reconocidos generalmente. El primero, que la globalización no instaura, sin más, un sistema económico mundial único, sino que es la suma caótica de procesos a menudo contradictorios que se autolimitan, donde convergen ámbitos estatales, locales, supranacionales y globales, esto desde el punto de vista territorial ${ }^{155}$. El segundo viene definido por la importancia de la instancia extraeconómica en la definición de las condiciones de acumulación que, en este momento, sigue siendo determinante. Desde esta perspectiva, se admite el papel decisivo del Estado en la configuración de la competitividad de su espacio geográfico en el contexto global.

Es por esto que algunos autores han señalado que la globalización se refiere no tanto al triunfo universal del capitalismo, como a la emergencia de un "mercado universal autorregulado"156. Podríamos entonces decir que el proceso de globalización es la vía de escape al control político de la economía. Autorregulación del mercado versus control político de la economía es el dilema que se plantea.

Así pues, la estrategia globalizadora incorpora decisiones políticas que construyen el nuevo marco de relaciones entre los sujetos actuantes en el mercado y que luego fundamentarán el paradigma dominante. Las decisiones políticas que introduce la globalización pueden formularse como sigue:

153 Garcia Herrera, M. A., y Maestro Buelga, G.: "Regioni, territorio e protezione sociale nella crisi dello Stato sociale», en Politica del Diritto, 2001, n. 1 , págs. $63-89$.

154 JESSOP, B., "Reflexiones sobre la (i)lógica de la globalización", op. cit.

155 VELTZ, P., "L'economie mondiale, une économie d'archipel», en Mondialisation au-delà des mithes, La Decouvertè, Paris, 1997, págs. 59-67. También SACHWALD, F., "La regionalisation contre la mondialisation?", en Mondialisation au delà des mithes, op. cit., págs. 133-146.

156 ADDA, J., La globalización de la economia: origen y desafíos, Sequitur, Madrid, 1999, pág. 105. 
a) Globalización se opone a regulación. La desregulación supone la primera decisión política que establece las bases de la relación política - economía del postfordismo. Ciertamente, esta relación es compleja y equívoca ${ }^{157}$, a la vez que se manifiesta de forma diversa en los distintos ámbitos. La contradicción, al menos formalmente, se establece por la correspondencia establecida entre regulación y política, es decir, regulación como manifestación del control económico. Sin embargo, vincular mercado a desregulación puede resultar problemático. El mercado es una institución económica artificial que no puede subsistir sin la regulación externa ${ }^{158}$, por esto mismo, cuando se analizan los procesos de desregulación nos encontramos con la paradoja del crecimiento de las normas reguladoras. Desregulación quiere decir, en este caso, sustitución de la regulación, lo que es lo mismo, disolución de los vínculos políticos anteriores. Con todo, existen ámbitos que influyen decisivamente en los comportamientos del sistema económico atenuando la eficacia del control nacional, donde, efectivamente, la desregulación adquiere la forma de liberalización. En el mercado de capitales la desregulación se expresa de este modo y sienta las bases para limitación de la política nacional ${ }^{159}$.

b) La liberalización de los mercados financieros. Aunque podría incluirse en la formulación anterior, su trascendencia obliga a singularizarla como una decisión que inicia el proceso.

La liberalización del mercado de capitales incide y se configura como la base de desvinculación de la política nacional, al menos desde dos perspectivas:

En primer lugar porque rompe con el sistema financiero internacional instaurado después de la II. a Guerra Mundial y que actuaba como una de las bases económicas del keynesianismo económico nacional ${ }^{160}$. En segundo lugar, porque la apertura de los mercados

157 AltVAter, E., "El lugar y el tiempo de lo político bajo las condiciones de la globalización económica", Zona Abierta, $n .^{\circ} 92-3,2000$, op. cit.

158 IRTI, N., "L'ordine giuridico del mercato", Laterza, Bari, 1998, págs. 535-40-44-47.

159 PLIHON, D., "Les enjeux de la globalisation financière", en La mondialisation au-delà des mythes», op. cit., págs. 69-79.

160 HIRST, P., "The global economy myths and realities", en International Affairs, 1997, n. 73 págs. 409-425; ADDA, J., La globalización de la economía: ori- 
financieros redefine la relación capital financiero-capital industrial perturbando el funcionamiento del sistema en su conjunto ${ }^{161}$.

c) Globalización se opone a Estado Social. Ya hemos aludido a cómo las novedades que incorpora el Estado Social, tanto en el ámbito genérico de la intervención económica de raíz keynesiana, como en la protección social, configurando el salario social como un factor del coste internacional de la producción sitúan a la estrategia globalizadora en confrontación con los elementos que caracterizan a esta forma de Estado. Si la globalización es sinónimo de la desvinculación política del control de la economía, de la ruptura del vínculo político por el mercado, supone esencialmente una ruptura de los mecanismos de integración del trabajo fundados por el Estado Social.

\subsection{La globalización financiera}

El proceso de liberalización de los mercados de capitales es singularmente paradigmático en relación con la caracterización de la globalización como estrategia de acumulación. Revela con claridad que la nueva configuración del sistema financiero es una decisión política de los Estados y que no obedece a una lógica económica intrínseca, inherente al mercado.

Como se sabe, el orden financiero internacional nace formalmente en 1944 con los acuerdos de Bretton Woods, de ellos nacen, tanto las bases del sistema monetario, como las instituciones de su gobierno. Se instaura un sistema basado en los cambios fijos derivados de una paridad determinada de todas las monedas respecto del dólar, la conexión del dólar con el patrón oro y el reconocimiento del dólar como moneda de intercambio y circulación internacional. Se completaba al sistema anterior con mecanismos de control de la circulación de capitales, altamente restrictivos y la creación de instituciones de gobierno del sistema: Banco Mundial y Fondo Monetario Internacional.

gines $y$ desafíos, op. cit., págs. 105 y 107; HeLleINER, E., States and the reemergence of global finance, op. cit.

161 Marazzi, C., E il denaro va. Esodo e rivoluzione dei mercati finanziari, Bolingheri, Turín, 1998, págs. 93-95. 
Este sistema de control de los mercados financieros no era sino la respuesta a la situación de los mismos desde los años 30, altamente inestables y en crisis cuasi permanente ${ }^{162}$. El sistema ideado en Bretton Woods era pues una solución política de estabilización del sistema económico internacional, que respondía a la evidencia de la imposible autorregulación del mercado.

Además, los acuerdos de Bretton Woods constituían una parte, la vinculada al sistema financiero internacional, del complejo de instituciones económicas que configuraron el círculo virtuoso keynesiano. La estabilidad cambiaria y el control de la circulación de capitales permitía la estabilidad de los tipos de interés y su contención y sentaba las bases de la autonomía económica de la política presupuestaria keynesiana (gobierno del ciclo a través de la intervención sobre la demanda). La coincidencia del ciclo cronológico de vigencia de Bretton Woods con el periodo de estabilidad y desarrollo del Estado social indica la funcionalidad de este mecanismo con las exigencias de intervención económica del Estado, de hecho, el principal elemento común entre la dimensión externa y la nacional del sistema económico era la intervención política del mercado. "La relativa estabilidad de los tipos de cambio observada en los años cincuenta y sesenta coincide, de hecho, con una fase muy específica de la historia financiera: la del predominio de un sistema público de financiación internacional y de la represión orgnizada de las finanzas privadas.

Una fase que coincide con el apogeo del Estado del bienestar en la mayoría de las democracias occidentales, es decir, de un sistema en el que la lógica del mercado quedó ampliamente reglada por la intervención pública en cuatro ámbitos principales: gestión coyuntural, política de la competencia y de precios, distribución de la renta y protección social. El sistema monetario y financiero internacional creado después de la guerra traspone, de algún modo, al ámbito internacional los principios organizativos internos de los Estados keynesianos» ${ }^{163}$.

De igual forma, la liberalización de los mercados financieros suponía la base para la inversión de la intervención económica del Estado, fijada en torno a la política monetaria, propiciada por el fin de la estabilidad de los cambios y a la lucha contra la inflación ${ }^{164}$. Signi-

162 ADDA, J., La globalización de la economia..., op. cit., pág. 89.

163 ADDA, J., La globalización de la economia..., op. cit., págs. 97-8.

164 MARAZZI, G., E il denaro va, op. cit., págs. 78-79. 
ficó el fin de los principios keynesianos de la actuación del gasto público y del déficit presupuestario en la intervención económica ${ }^{165}$.

La ruptura del sistema de Bretton Woods fue también una decisión política, una estrategia de desvinculación política del mercado, base para futuras liberalizaciones ${ }^{166}$.

Por ello, el proceso de globalización financiera ha sido explicado por algunos autores como la historia de las decisiones políticas liberalizadoras protagonizadas por los Estados ${ }^{167}$. Tres tipos de decisiones políticas adoptadas por los países desarrollados han sido determinantes en la definitiva destrucción del sistema de Bretton Woods.

En primer lugar, la introducción de dosis, cada vez mayores, de permisibilidad y liberalización en la circulación de capitales. El entramado institucional de los acuerdos de 1944 establecía mecanismos de control sobre la circulación de capitales, así el artículo IV de los estatutos del F.M.I. autorizaba el control de los movimientos de capital y éste fue profusa y severamente utilizado hasta finales de la década de los cincuenta. Sin embargo, en lo que Adda ha llamado la primera fase de la globalización financiera ${ }^{168}$, que corresponde con la "emergencia del mercado de los eurodólares» ${ }^{169}$, desde finales de los cincuenta, pero más claramente por el aumento de su importancia en la década siguiente, se crea un mercado europeo de dólares no sujeto a controles estatales. Los intermediarios bancarios trabajan con divisas distintas de la moneda nacional y fuera de las fronteras de los paises de origen, por lo que se sustraen a los controles establecidos para la circulación de las monedas nacionales convertibles. La decisión política de permitir operadores de mercado con un grado importante de libertad, que consolida el euromercado de Londres, apoyado por Inglaterra y Estados Unidos, significó ya una ruptura del sistema instaurado en la inmediata postguerra. Esta inicial política liberalizadora alcanza cotas cualitativamente determinantes a mediados de los años setenta con la abolición paulatina del sistema de controles creado al amparo de Bretton Woods. Estas liberalizaciones permitieron la consolidación de un mercado financiero ajeno a las instituciones internacionales que,

165 MarazzI, G., E il denaro va, op. cit., págs. 78-79.

166 Ferrara, G., "Lo "Stato pluriclasse" protagonista del "secolo breve"", en Dallo Stato monoclasse alla globalizzazione, op. cit., págs. 73-100.

167 HeLleINER, E., States and the reemergence of global finance..., op. cit., págs. 8-12.

168 ADDA, J., La globalización de la economia..., op. cit., págs. 90-2.

169 ADDA, J., La globalización de la economía..., op. cit., pág. 90. 
hasta entonces, habían canalizado el sistema de préstamos y ayuda financiera a los Estados. La afluencia de los petrodólares, en los momentos sucesivos a la primera crísis energética, consolidó este mercado y permitió a las finanzas internacionales escapar del sistema público. Este proceso culmina con la práctica supresión de los controles al tráfico de capitales en los países desarrollados durante los años ochenta.

Junto a las medidas liberalizadoras expresas, se sitúan otro tipo de decisiones de los Estados, consistentes en rechazar la intervención en la circulación de capitales, prevista en los acuerdos de Bretton Woods, incluso en las situaciones de crisis creadas durante el proceso de extensión del mercado libre de capitales. En opinión de Helliner, estas decisiones políticas han sido poco estudiadas por la literatura sobre la globalización financiera ${ }^{170}$.

La renuncia al uso de controles en los momentos de crisis del sistema supuso un punto de inflexión en la competencia entre el mercado libre de capitales y las instituciones reguladas. Resultó ser un espaldarazo a la consolidación y hegemonía del mercado global financiero. Los momentos más expresivos de estas intervenciones negativas se dan precisamente en la fase de hundimiento de Bretton Woods, desde mediados de los setenta hasta los ochenta ${ }^{171}$.

A la intervención negativa citada, entre los años setenta y ochenta del siglo pasado, sigue una radical tendencia a la liberalización del mercado. A comienzos de los 90 , puede decirse que no queda nada del sistema ideado en 1944, supone la tercera fase de la globalización, la consolidación definitiva del mercado de capitales como espacio libre y global172. La liberalización se complementa con una serie de intervenciones tutelares del mercado que tienden a limitar los efectos de su inestabilidad. Estas intervenciones tienen la finalidad de salvaguardar el mercado global, consolidando definitivamente la nueva situación, son pues funcionales a la liberalización. Ese es el significado de la colaboración política del G7 y sus bancos centrales ${ }^{173}$.

pág. 9.

170 HeLleINER, E., States and the reemergence of global finance..., op. cit.,

171 KAPSTEIN, E. B., Governing the global economy. International finance and the State, Marrard University Press, Cambridge, Londres, 1994, págs. 30-57.

172 Para una descripción del proceso en los países claves ver HELLEINER, E., op. cit., cap. 7, págs. 146-56.

173 Para una descripción del proceso en los países claves, ver HeLleINER, E., op. cit., cap. 7, págs. 11-12. 
La globalización financiera no sólo resulta ser la avanzada del proceso de globalización económica, sino que opera efectos en el conjunto del sistema. Así, la organización pública, estatal, del mercado financiero global condiciona el comportamiento del sistema, proporcionando las bases legitimadoras de las nuevas políticas públicas.

Los mercados financieros globales determinan el funcionamiento de los sistemas económicos nacionales. En una situación de libertad de circulación de capitales, la valorización del capital se realiza en el ámbito de los mercados financieros ${ }^{174} \mathrm{e}$ impone sus condiciones al conjunto del sistema. La localización del capital condicionada por la exigencia de altas tasas de valorización del capital en el corto plazo y la tendencia a la especulación como comportamiento generalizado del sistema financiero perturba el sistema económico y rompe con la determinación de los beneficios del aparato productivo nacional. La crisis de Méjico de finales de 1994 ilustra esta capacidad de condicionar el comportamiento económico general ${ }^{175}$.

La globalización financiera trastoca la relación entre el capital financiero y el capital industrial. La descripción de Hilferding respecto al surgimiento del capitalismo monopolista y a su hegemonia, que comportaba una fusión entre ambos capitales, muta sustancialmente para pasar a una hegemonía del capital financiero en el sistema. La localización del capital, la decisión de la financiación y la inversión obedece a la lógica especulativa y confirma la disociación entre economía financiera y productiva ${ }^{176}$. Se sanciona la desconexión entre la esfera financiera y la productiva ${ }^{177}$, esta ruptura se manifiesta en la desproporción de los flujos comerciales y financieros. Los datos indican que, en la década de los noventa, el importe de las transacciones financieras internacionales fue cinco veces mayor que el valor del comercio de mercancías y servicios.

Ese dato indica de forma expresiva la hegemonía del capital financiero en la definición de los términos de la valoralización del capital. La relación entre ambos capitales explicaba el auge de la empresa fordista en la organización de la producción y la importancia de ésta en las condiciones de extracción del plusvalor. La inversión de la rela-

174 AltVATER, E. "El lugar y el tiempo de la política bajo las condiciones de la globalización económica", op. cit.

175 PLIHON, D., "Les enjeux de la globalisation financière", op. cit.

176 MARAZZı, C., E il denaro va, op. cit., pág. 94.

177 PLIHON, D., "Les enjeux de la globalisation financière", op. cit. 
ción, el establecimimento de las condiciones de la reproducción del capital en base a las exigencias del mercado global de capitales fruto de la hegemonia del capital financiero redefine el funcionamiento del sistema. Es desde estos ámbitos desde donde se establecen las condiciones de competencia, extendiendo su influencia a la totalidad de los mercados, incluyendo el de trabajo.

Pero esto no es sino la consecuencia de la nueva estrategia de acumulación, no el resultado de determinismos irresistibles.

Así pues, considerada desde esta perspectiva, la globalización como estrategia de acumulación, pretende legitimar la disolución de los vínculos políticos establecidos por la constitución económica del Estado social. Globalización se opone a la relación política-economía construida por el constitucionalismo social.

La nueva relación entre estos espacios, en el marco del postfordismo, invierte la primacía política que se torna en centralidad del mercado. Los procesos gestados desde la década de los ochenta no suponen, a pesar de las fórmulas usadas para describirlos, el fin del intervencionismo público, sino uno nuevo, caracterizado por la subordinación de la política dirigida a resolver las contradicciones que al proceso de acumulación creaba el modelo del Estado social. Conviene, desde estas consideraciones, recuperar los elementos del debate presentes en la construcción conceptual de la constitución económica en orden a perfilar, siquiera, algunos contornos de la nueva intervención pública, de la definición de la relación política economía postfordista.

Una literatura politológica que cobra particular relieve desde los ochenta del pasado siglo propone una confrontación de modelos, opone al Estado interventor, el Estado regulador ${ }^{178}$, paradigma de la nueva intervención. Los análisis sobre la desregulación no sugieren el fin del modelo regulador, sino la corrección del mismo, desregulación como re-regulación ${ }^{179}$, acentuando los rasgos de centralidad del mercado en sus relaciones con la política. Se trata, entonces, de una readaptación del modelo que mantiene sus contornos originales, es decir, la primacía de la lógica económica y la funcionalidad de la intervención pública al pleno desarrollo de ésta.

178 MAYONE, G., "The rise of the RegulatoryState in Europe", en West European polities, 1994, vol.17, n. ${ }^{\circ}$ 3. págs. 77-101; LA SPINE, A., y MAHONE, G., Lo stato regolatore, II Mulino, Bolonia, 2000, págs. 33-5.

179 MAHONE, G., Y LA SPINE, A., "“Deregulation" e privatizzazione: diferenze e convergenze», en Stato e mercato, 1992, n. ${ }^{\circ} 35$, págs. 249-290. 
Como puede verse, Estado regulador no es una novedad doctrinal, sino que supone la reaparición de una lectura de la constitución económica, aquella de la escuela de Friburgo que encarnaba las posiciones del ordoliberalismo. No es de extrañar que los intentos de caracterización de la constitución económica europea se hagan desde esta perspectiva ${ }^{180}$, oponiendo, también, intervencionismo a economía de mercado.

\section{EL ESTADO REGULADOR}

\subsection{Estado regulador y Estado social}

Aunque la literatura americana sobre la regulación se vincula con la escuela de la public choice y las teorías sobre los fallos del mercado, el marco ambiental europeo es el proceso de liberalización económica manifestada en la oleada de privatizaciones de los sectores antes vinculados a la construcción de los servicios públicos. La década de los ochenta del siglo pasado es también el inicio de la revisión de los mecanismos de intervención pública en la economía y de los sistemas de protección social, es decir, de la transición el Estado social a la nueva forma de Estado, de la que el Estado regulador no es sino una de sus interpretaciones.

En el entorno europeo, las interpretaciones que utilizan este nuevo paradigma, se ven favorecidas por los impulsos liberalizadores protagonizados por la CEE, iniciados ya con el Acta Única y consolidados plenamente con el Tratado de Maastricht ${ }^{181}$. Guarino otorga al condicionamiento comunitario un papel determinante en la evolución y transformación de la constitución económica del Estado social, estableciendo como nuevo principio la centralidad del mercado ${ }^{182 .}$

180 Caronna, F., "Qualque spunto sull'evoluzione della costituzione economica dell'Union Europea", en Ars Interpretandi, 2001, n. ${ }^{\circ} 6$, págs. 271-94.

SAUTER, W., "The economic constitution of the European Union", en Columbia Journal of European Law, 1998, n. ${ }^{\circ}$, págs. 27-68.

181 MAJONE, G., "The rise of the regulatory state in Europe", en West European Politics, 1994, vol. 17, n. ${ }^{\circ} 3$, págs. 77-111; del mismo autor, "The European Community as a Regulatory state", en Collected courses of the Academy of European Law, 1994, vol. V-1, págs. 321-419. ABAGNALE, G., "Autorità independente e Trattato di Maastricht", en La autorità independenti nei sistemi istituzionali ed economici, Passigli, Ed. Florencia, 1997, págs. 117-44.

182 GUARINO, G., "Le autorità garanti nel sistema giuridico", en Autorità independente el principi costituzionali, Cedam, Padua, 1999, págs. 31-48. 
Ciertamente, la mayoría de la doctrina no tiene una aproximación global al Estado regulador, sino que su tratamiento es derivado de la singularización de sus instituciones más características: las autoridades independientes. Sin embargo, esto no es obstáculo para que el análisis de sus características y funciones reconduzcan a los problemas de la ruptura de la constitución económica del Estado social.

La primera aproximación al Estado regulador es de carácter negativo, sus rasgos definidores se configuran en contraposición al Estado social. Es cierto que en la confrontación entre ambos tipos de Estado la literatura suele usar el concepto de Estado empresario ${ }^{183}$, pretendiendo una diferenciación entre Estado social y el uso perverso de determinados instrumentos de intervención económica, pero resulta evidente que esta elusión terminológica no empaña la oposición entre el Estado social y las nuevas formas de intervención.

Estado regulador se opone a formas de intervención vinculadas a conceptos como "Estado keynesiano" o "Welfare state keynesiano" ${ }^{184}$ y más explícitamente al desarrollo materializado en Europa durante las décadas de oro del Estado social.

"Mientras por razones, sea históricas, sea empíricas, sea conceptuales, Estado regulador y Estado interventor/gestor directo se presenten como opuestos..., no está dicho que Estado regulador y Welfare State sean entre sí incompatibles. Una vez fijada la noción de Estado regulador, esto dependerá de lo que entendamos por Welfare State. En realidad, si éste viene visto como necesariamente conexo al positive state y a su práctica del déficit spending, y caracterizado por políticas lo más universalistas posibles, gestionadas directamente por burocracias públicas escasamente controlables y monopolistas de los respectivos servicios, no ya por una lista de derechos $y$ necesidades sociales tendencialmente ilimitada, es cuanto menos previsible una tensión sobre el plano histórico y sobre el empírico» ${ }^{185}$.

Se pretende compatibilizar Welfare State, o mejor, el resultado de la revisión de los modelos de protección en la crisis del Estado

183 Roppo, V. "Privatizzazioni e ruolo del "pubblico": lo stato regolatore", en Politica del diritto, 1997, n. ${ }^{\circ} 4$, págs. 627-38. PreDIERI, A., L'erompere della autorità amministrativa independente, Passigli Fol. Florencia, 1997, págs. 78-9. pág. 10.

184 LA SPINA, A., y MAHONE, G., Lo stato regolatore, II Mulino, Bolonia, 2000,

185 La SPINA, A., y MaHONE, G., op. cit., págs. 33-4. 
social, con el Estado regulador, concebido como Estado limitado ${ }^{186}$, cuyas fronteras con el concepto de Estado mínimo resultan confusas y no fácilmente definibles.

Desde la perspectiva constitucional, si no resulta fácilmente admisible la identificación entre "Estado del bienestar» $y$ "Estado social", mucho menos es posible una reconducción del Estado social al concepto de Estado limitado.

Más evidente es la diferenciación de modelos que establece Guarino, contraponiendo los principios del nuevo Estado impuesto por los procesos de liberalización al diseño constitucional. La oposición, así, resulta radical: autonomía del mercado y gobierno de la economía resultan incompatibles. El problema trasciende a la nueva crítica del uso y del resultado de determinados instrumentos de intervención para afirmar una primacía cuasi-absoluta: el mercado. "El Estado no puede influir sobre el mercado, es decir, sobre las empresas, es decir, sobre la capacidad productiva de las empresas. Estímulos al mercado pueden darse en áreas limitadísimas... o de forma indirecta, creando condiciones ambientales más favorables a la producción» ${ }^{187}$.

El marco conceptual que sirve de límite al Estado regulador vuelve a ser, ahora, el de la "economía de mercado", lo que explica la autolimitación del Estado en el tránsito de la economía organizada a la economía de mercado pues, sólo dentro de los límites de ésta, es posible la acción pública ${ }^{188}$.

La doctrina destaca dos rasgos que caracterizan al Estado regulador, además de su oposición al intervencionismo propio del Estado social, estas son: la intervención mediante reglas y el respeto a la «lógica de acción de los sistemas regulados» 189.

Frente a la intervención directa, en la que el Estado actúa como operador autónomo productor de bienes y servicios y distribuidor directo, se contrapone un Estado productor de reglas. Reglas que tienen por objeto contribuir al funcionamiento del mercado. La intervención externa normativa pretende corregir los efectos perversos del funcionamiento del mercado sobre la base del respeto a su autonomía y normas que la definen.

186 LA SPINA, A., y MAHONe, G., op. cit, pág. 34.

187 GUARINO, G., "Le autorità garanti nel sistema giuridico", op. cit.

188 PreDIERI, A., L'erompere delle autórità amministrativa independenti, op. cit., pág. 78.

189 LA SPINA, A., y MAHONE, G., Lo stato regolatore, op. cit., pág. 33. 
Se trata pues de recuperar las viejas formulaciones de la economía social de mercado ${ }^{190}$ en la que la intervención pública era funcional a la existencia del mercado, o mejor garante de su existencia, la heterocorrección de la acción pública tiende a asegurar unas condiciones de funcionamiento que, en sustancia, preservan la institución y autonomía, a la vez que consagran su absoluta centralidad.

Desde esta perspectiva, el postulado central del Estado regulador conduce a una nueva diferenciación de los ámbitos políticos y económicos. Ciertamente, no es la formulación decimonónica, que sólo tuvo virtualidad ideológico-teórica, pero, en la medida en que postula la autonomía del mercado y rechaza la intervención política en su funcionamiento, no hace sino proponer la existencia de un espacio natural con lógica propia: la ecorrómica. La función del Estado se limita a garantizar, en las mejores condiciones posibles, su funcionamiento, de ahí la teorización de una función subalterna del poder público cuyo ámbito de intervención-regulación sea la garantía de las condiciones de competencia.

La oposición entre Estado regulador y Estado social y de sus constituciones económicas deriva de esa posición subalterna del Estado de la pérdida de la dirección política de la economía que era la que definía la superación de espacios propios del Estado liberal.

"En este sentido, podemos decir que, en las democracias que alcanzan un cierto grado de maduración, la tutela del mercado - donde el mercado se entiende genéricamente una forma de organización de la sociedad - funciona como límite al indirizzo político del gobierno»191.

\subsection{Los instrumentos de regulación: las autoridades independientes}

En el marco anteriormente descrito, tiene importancia detenerse en los instrumentos de la regulación en la medida en que contribuyen a verificar esta inversión de las relaciones entre política y economía propia de la forma de Estado, que surge tras la ruptura del cit., pág. 79.

190 PredieRI, A., L'errompere delle autorità amministrative independenti, op. pág. 239.

191 PASSARO, M., Le amministrazioni independenti, Giappichelli, Turín, 1996, 
Estado social. Las autoridades independientes simbolizan el tránsito al nuevo Estado, la ruptura de la Constitución económica, del constitucionalismo social y, desde esta perspectiva, se convirten en el paradigma del Estado regulador ${ }^{192}$.

El fenómeno de las autoridades independientes no es desligable del proceso de liberalización que en la Europa comunitaria se impulsa desde el Acta única. La privatización de los espacios de intervención pública directa vinculados a los servicios públicos, fruto de la liberalización, obliga a introducir cautelas en el funcionamiento de los nuevos mercados sectoriales tendentes, tanto a preservar la competencia, como a garantizar unos standards frente a los consumidores. La retirada del Estado es la que impone una forma de intervención en los nuevos espacios abiertos a la competencia cuyo objeto es su garantía. Por ello, las autoridades administrativas independientes expresan la sustitución del gobierno político de la economía por la autonomía del mercado ${ }^{193}$ simbolizan el fin del indirizzo político del Estado en materia económica. Este tipo de instrumentos emergen y se imponen como fruto de la nueva lógica económica y sólo se entienden desde ella. "Lo que importa es que los mercados han impuesto su lógica de existencia concurrencial imponiendo al legislador la creación de administraciones desvinculadas del indirizzo políticon 194.

Aunque es evidente que no existe un único modelo de este tipo de órganos y que tanto las funciones, como los poderes son diversos en los ya numerosos ejemplos de éstos ${ }^{195}$, sí pueden resaltarse algunos rasgos que los caracterizan.

El más llamativo es obviamente el de la independencia. Además de algunos elementos presentes en los requisitos para la designación de sus miembros, referidos a la cualificación técnica y relevancia profesional, independencia quiere expresar la ruptura de la dependencia jerárquica con los órganos políticos, con el gobierno.

192 PREDIERI, A., L'errompere delle autorità amministrative independenti, op. cit., pág. 81.

193 MANETTI, M., Voz "Autorità independenti (Dir. Cost.)". Enciclopedia giuridica, Istituto della Enciclopedia Italiana (G. Trecani), Roma, 1995.

194 MERUSI, F., "Considerazioni generali sulle amministrazioni independenti”, en Mercato e Amministrazioni independenti, Giuffré, Milán, 1993, págs. 151-61.

195 De Siervo, U., "Le diversità fra la varie autorità", en Autorità independenti e principi costituzionali, op. cit., págs. 69-71. 
Pero la nota de la independencia tiene además, al menos, otras de las consecuencias en su diseño. Por un lado, la prevalencia de los criterios técnicos para la adopción de las decisiones y la ausencia de responsabilidad respecto a las mismas, que, salvo el control jurisdiccional a posteriori, no existe. La exclusiva sujeción a la ley, las configura como espacios de decisión exentos de control, sustrayéndolas a la lógica democrática que preside el resto del sistema político. Por ello, la independencia simboliza la retirada de la política, del indirizzo, de la esfera del mercado.

La independencia como desvinculación del indirizzo político y ausencia de responsabilidad es consecuencia de las funciones asignadas. Dejando al margen algunas autoridades garantes de derechos, especialmente, las que despliegan sus actividades en la protección de datos, estas administraciones cumplen esencialmente dos funciones: la primera y esencial es la garantía de la competencia en los ámbitos sectoriales de regulación, la segunda, asegurar estándares de protección de los servicios a los usuarios. Estas últimas constituyen el residuo tutelar de la lógica del servicio público que, ahora, se compatibiliza con el mercado.

La primacía de las funciones de heteroprotección del mercado refuerzan la independencia y los criterios técnicos en su actuación, porque éstos no suponen sino la traducción de la autonomía de la esfera económica y su exclusión del gobierno político de la misma.

Estas características de las autoridades independientes han motivado su confrontación con el constitucionalismo social creando serias dudas sobre su legitimidad.

Como resulta evidente, los problemas de constitucionalidad derivan de esos dos rasgos que los caracterizan, que definen su independencia; por una parte su sustracción al indirizzo político, que contraría la constitución económica del Estado social y, por otra, la ausencia de responsabilidad. Aunque en cada constitución se contienen normas diferentes que determinan el régimen de la administración, los problemas que plantean este tipo de órganos son similares puesto que se confrontan con los principios emanados del Estado social. A este respecto, es ilustrativo el debate italiano. Respecto a la ausencia de responsabilidad, producto de su colocación fuera de los circuitos administrativos normales y de la ausencia de dependencia del gobierno, alguna doctrina ha formulado la compatibilidad con el principio democrático a través de distintas vías. 
En algún caso, la constitucionalidad se proclama vinculada con la aplicación del principio de descentralización administrativa que permitiría la separación de los órganos de indirizzo y su puro sometimiento, exclusivo, a la ley ${ }^{196}$. La descentralización funcional encontraría su legitimación en la pluralidad de modelos que admitiría el principio no reconducible a una lógica territorial. Ciertamente, este planteamiento no resuelve, allá donde tenga suficiente soporte constitucional, el problema de la falta de responsabilidad, y resulta obvio que las funciones asignadas a estas entidades administrativas, per se, no justifican su independencia.

Menor fundamento tiene la propuesta de basar la legitimidad de las autoridades independientes en el procedimiento ${ }^{197}$, dándole a éste prevalencia sobre el principio democrático. Los procedimientos consensuales y de participación, por otra parte fruto de las dinámicas políticas instauradas en el Estado social, no pueden contraponerse al principio democrático $y$, menos aún, proponerse como alternativa al circuito de la representación político-electoral ${ }^{198}$.

La dificultad de admitir la legitimidad constitucional, aceptada mayoritariamente por la doctrina ${ }^{199}$ ha dado lugar a propuestas más cautelosas. Dado que el problema se plantea respecto a las autoridades con poder de regulación, se ha entendido que su constitucionalización debe conectarse con el ordenamiento comunitario, en la medida en que muchas de estas "constituyen las terminales privilegiadas de la normativa comunitaria en nuestro ordenamiento, y su independencia es instrumento de la prevalencia del derecho comunitario» 200 . En todo caso, esto no salva el contraste, sino que lo sitúa en la colisión entre el ordenamiento comunitario y el constitucional, expresión del Estado social.

Junto a los problemas señalados surge el núcleo duro de la confrontación entre las constituciones del constitucionalismo social y las

196 PREDIERI, A., L'erompere delle autorità amministrativa independenti, op. cit., págs. 50-54.

197 PASSARO, M., Le amministrazioni independenti, op. cit., págs. 245-257.

198 PASSARO, M., op. cit., págs. 254-7.

199 VERGOTTINI, G., "L'autorità di regolazione dei servici pubblici e il sistema costituzionale dei pubblici poterin, en Attività regolatoria e autorità independenti, Giuffré, Milán, 1006, págs. 3-17.

200 MANETTI, M., "Le proposte di riforma costituzionale in materia di autorità independenti”, en Autorità independenti e principi costituzionali, Cedam, Padua, 1997, págs. 175-85. 
autoridades independientes, el del rechazo al indirizzo económico por parte del poder político y la recuperación de la autonomía del mercado. Las autoridades independientes, en cuanto reflejan una tensión irreconciliable con las constituciones económicas del Estado social, significan la ruptura de éstas; "la progresiva afirmación del mercado, hasta conseguir su completo dominio, es el dato institucional que está modificando nuestra convivencia y que ya ha transformado el vigente régimen constitucional y administrativo" 201.

El principio de autonomía del mercado que consagran las autoridades independientes y su centralidad resulta incompatible con el gobierno político del sistema económico que se expresa, precisamente, a través de la vinculación de la economía al interés general, definido políticamente. Los instrumentos de intervención económica del Estado reflejan el vínculo social del sistema y traducen la relación política-económica ahora rota. Por ello el problema de la constitucionalidad de las autoridades independientes es, primariamente, la contradicción de la constitución económica, de la que son manifestación, con el Estado social. Así planteada, la contradicción es irresoluble.

Esta tensión se manifiesta en la relación entre interés general o social, base de la vinculación del sistema económico, y los intereses tutelados por la regulación y la intervención de las autoridades independientes.

Dado que la función esencial de estos órganos consiste en la garantía de la competencia en los sectores reguladores, o bien, el interés general se construye desde el mercado, o, por el contrario, éste subordina al interés social, que se define desde la política. El correcto funcionamiento del mercado no puede ser un principio contrapuesto al interés general ni su condicionante.

Por otra parte, resulta evidente, más allá de esta consideración general, que los intereses tutelados por estas autoridades no pueden reconducirse en muchos casos al interés social como vínculo del sistema económico. Resulta obvio que, tanto por los destinatarios, como por los intereses protegidos, éstos son fragmentarios ${ }^{202}$ y por su naturaleza desde ellos no puede construirse una vinculación general del mercado compatible con el Estado social. Ni los ahorradores, ni siquiera el consumidor, como categoría distinta del ciudadano, puede ser la

201 GUARINO, G., "Le autorità independenti nel sistema giuridico», op. cit.

202 PASSARO, M., Le amministrazioni independenti, op. cit., pág. 266. 
fuente vinculante del sistema, desde la que se construye el interés general, que constitucionalmente sustenta el gobierno de la economía. La diferencia conceptual entre interés general y el mosaico de intereses fragmentarios tutelados por estos órganos parece evidente ${ }^{203}$.

Desde la perspectiva aqui analizada, el Estado regulador resulta ser la expresión del paradigma impuesto por la globalización en las relaciones Estado-economía. Consagra la autonomía del mercado y la prevalencia de sus normas de funcionamiento y desplaza a la política (Estado) a las funciones de tutela de sus reglas. El espacio de la heterocorrección no es sino la funcionalización de la política, de esta forma, desaparece la contradicción entre Estado y globalización, puesto que la actuación de éste, se sitúa en posición coadyuvante para la generalización del mercado, permeabilizando el conjunto de las realciones sociales.

\section{LA CONSTITUCIÓN ECONÓMICA EUROPEA}

No es el lugar, este trabajo, para referirse a la legitimidad del uso del término constitución en el contexto del Ordenamiento comunitario. Por ello, a los efectos de mostrar las lógicas contradictorias entre el Estado social y el Ordenamiento comunitario, usaremos el término constitución económica. Por otra parte, puede entenderse que las críticas ya comentadas respecto a la inadmisibilidad terminológica, en cuanto puede aludir a la autonomía de la economía respecto al orden constitucional en su conjunto, parecen, en este caso, menos decisivas, puesto que la constitución económica opera, en el ordenamiento comunitario, como verdadera constitución material de la Comunidad, e incluso de la Unión Europea ${ }^{204}$. La economía, en el ordenamiento europeo, actúa como fuente de irradiación desde la que se construye el conjunto del sistema jurídico.

El acercamiento a la constitución económica lo haremos desde una perspectiva general y sin una referencia exhaustiva de detalle a las previsiones contenidas en el derecho originario; lo que nos impor-

203 Chevallier, J., "La place du service public dans l'univers juridique contemporain", en Le service public en devenir, L'Harmattan, París, 2000, págs. 21-35.

204 BILANCIA, F., "Brevi note su costituzione mateiale, legalità ed Unione Europea", en La costituzione materiale. Percorsi culturali e attualita di un'idea, Giuffrè, Milán, 2001, págs. 425-43. 
ta es analizar la tensión político-económica y su relación en el «nivel constitucional» del ordenamiento.

En las primeras contribuciones sobre la constitución económica comunitaria, en la década de los setenta del siglo pasado, ya plantean la cuestión, si bien, de forma indirecta, relacionándola con la construcción teórica del concepto, es decir, con la propuesta de la economía social de mercado de la escuela de Friburgo, aunque sus análisis son prevalentemente descriptivos ${ }^{205}$. El debate resulta más explícito en la década de los noventa, como consecuencia de las transformaciones operadas por las modificaciones del Tratado de Roma. Las posiciones doctrinales se sitúan ahora en torno a dos posturas: la recepción de la idea de la "economía de mercado", remitiéndose en sus formulaciones a la ya mencionada escuela de Friburgo ${ }^{206}$, y la neutralidad constitucional del Ordenamiento comunitario, rechazando la rígida subordinación de éste a las exclusivas normas del mercado ${ }^{207}$.

En nuestra opinión, el debate resulta distorsionado en ambos planteamientos. En el primer caso, la remisión al ordoliberalismo como definición del modelo de referencia con el que confrontar la constitución económica europea es parcial y la reconstrucción de sus postulados se realiza, más sobre la base de las propuestas de Hayek, que sobre las aportaciones de los fundadores de la escuela. Tal y como ha señalado la doctrina ${ }^{208}$, entre el radicalismo de Hayek en la definición de la "economía de mercado" y la propuesta de la "economía social de mercadon existe una diferencia, exactamente aquélla que caracteriza a la escuela de Friburgo como innovadora respecto al pensamiento económico liberal.

El reconocimiento, como hemos señalado con anterioridad, del papel de los poderes públicos, tanto en la institucionalización del mercado y la protección en el ámbito social, como en la política económica de coyuntura, forma parte sustancial de la propuesta, es más, define la novedad de la propuesta de la "economía social de mercado".

205 Constantinesco, L.-J., "La constitution économique de la CEE», en Revue trimestrielle de droit europeen, 1997, págs. 239-64.

206 Streit, M. E., y Mussler, W., "The economic constitution of the European Community: From "Rome" to "Maastricht" ", en European Law Journal, 1995. n. ${ }^{\circ} 1$, págs. 5-30.

207 SAUTER, W., "The economic constitution of the European Union", en Columbia Journal of European Law, 2998, n. ${ }^{\circ} 4$, págs. 27-68.

208 Caronna, F,. "Qualche spunto nell'evoluzione...", op. cit. 
Por otro lado, si tenemos en cuenta la pretensión de fundar las políticas comunitarias en los objetivos sociales y en los espacios nuevos de intervención comunitario, abiertos tras las nuevas reformas de los tratados, la neutralidad constitucional respecto a los modelos económicos, parece a todas luces forzada. Los intentos de recuperar una conexión de la constitución económica comunitaria con la idea de "economía mixta" referida al Estado social desconoce el papel subalterno y con funciones prevalentemente de legitimidad residual de las intervenciones comunitarias en el ámbito social, al menos, desde el punto de vista del derecho originario y de la evolución actual de la jurisprudencia europea.

Por ello mismo, nos parece sostenible una caracterización de la constitución económica europea en base a la propuesta de la "economía social de mercado". La evolución de los tratados no desmiente los postulados de la escuela de Friburgo, al contrario, la Comunidad cierra el círculo de su evolución con una recuperación más prístina de sus formulaciones. Huelga decir que, en nuestra reconstrucción de la constitución económica del Estado social, la propuesta de la escuela de Friburgo no es conciliable con la relación entre Estado y economía que se deriva de esta forma de Estado.

\subsection{Las aproximaciones a la constitución económica europea}

Como hemos dicho, una primera propuesta ha caracterizado la constitución económica vinculándola a la idea de "economía de mercado", si bien, introduciendo dudas sobre la pervivencia del modelo en la evolución de los tratados.

Para esta doctrina, la autonomía del mercado y de sus reglas, expresión de un sistema autoorganizado, era interiorizada por el Tratado de Roma, que constitucionalizaba el sistema de mercado.

Las cuatro libertades básicas permitían la autocoordinación de los actores del mercado. El principio de libre competencia aseguraba la autorregulación del mercado. Igualmente, el objetivo de la Comunidad, como definidor de los ámbitos de intervención comunitaria y de límite de la misma permitía una clara separación de los espacios público y privado y la subordinación del primero al segundo ${ }^{209}$. Este marco de referencia suponía la recepción de la economía de mercado 
en su definición vinculada a la formulación de Hayek. Más aún, los caracteres del ordenamiento comunitario, especialmente su supremacía frente al derecho estatal, dotaba de una fuerza expansiva a su constitución económica frente al constitucionalismo social. Ciertamente, había algunas sombras en el Tratado de Roma, las políticas comunitarias, en especial, la agrícola, introducian una lógica interventora que perturbaba la definición y absoluta prevalencia del mercado, aunque no rompía la relación entre intervención y la construcción del espacio libre del mercado.

El Acta Única y, posteriormente, el Tratado de Amsterdam introducen elementos de inversión de la lógica antes expuesta, estableciendo una convivencia de principios contradictorios. El Acta Única, con su referencia a la cohesión económica y social, proporciona la base legal para el intervencionismo y la dirección política del sistema econímico. Maastricht supone, desde estas propuesta doctrinales, el cambio constituciona| ${ }^{210}$, interiorizando los principios contradictorios de la economía de mercado y la intervención en un doble sentido, la derivada de los objetivos sociales y la de la apertura del espacio de la política económica comunitaria. La definición de los objetivos previstos en el art. 2 y los medios del art. 3, acreditarían la inversión constitucional, asi se concluye con una afirmación especialmente radical: "Desde una perspectiva económica, el concepto de competencia revelado por el texto del Tratado y por la práctica de la Comisión es completamente diferente desde la visión de la compatibilidad con las propiedades funcionales del sistema de mercado" ${ }^{211}$. De esta forma, los Tratados, en sus últimas versiones, habrían transformado una constitución económica, definida por la económica de mercado, en un sistema de "cartelización de intereses" ${ }^{212}$ de naturaleza corporativa.

Frente a esta propuesta, las aportaciones mayoritarias coinciden en afirmar la dificultad para la definición de la constitución económica europea en terminos de economía de mercado hayekiana ${ }^{213}$.

210 Streit, M. E., y MUSSler, W., op. cit.

211 StREIT, M. E., Y MUSSLER, W., op. cit.

212 STREIT, M. E., Y MUSSLER, W., "The economic constitution...", op. cit.

213 SAUTER, W., "The economic constitutions...", op. cit.; CARONNA, F., "Qualche spunto...", op. cit.; CASSETTI, L., La cultura del mercato fra interpretazioni della costituzione e principi communitari, Giappichelli, Turín, 1997, cap. III, págs. 183-226; CANNIZZARO, E., "Sussidiarietà e interventi di riequilibrio el emrcato commune», en Fondi strutturali e coessione eonomica e sociale nell'Unione Europea, Giuffrè, Milán, 1996, págs. 135-46. 
El punto de partida para la afirmación de la neutralidad de la constitución económica comunitaria, construcción que recuerda la conocida tesis de la doctrina y jurisprudencia alemana respecto a su constitución ${ }^{214}$, y la aproximación a la lógica de la economía mixta ${ }^{215}$ es el de llegada de los postulantes de la economía de mercado.

El Tratado de Amsterdam presenta como novedades la institucionalización de la Unión Europea y en torno a ella una nueva definición de objetivos, que trasciende la lógica establecida en Roma y en los Tratados constitutivos. La consecución de los objetivos contenidos en el artículo 3 supondrían una ampliación tanto de espacios, como de formas de actuación que, en opinión de Sauter, desmiente la centralidad absoluta del mercado y abre la vía a la afirmación de la neutralidad de la constitución económica europea. La clave esta en su afirmación de que la nueva redacción de los tratados no establece jerarquia en los objetivos, ni en los instrumentos a utilizar ${ }^{216}$.

La alusión al principio de neutralidad de los Tratados en materia del régimen de propiedad y la compatilidad entre la iniciativa pública y privada, así como la posibilidad de excepcionar la aplicación de las normas sobre la concurrencia (art. 86,2 Tr. Amst.) permiten hablar de la introducción de mecanismos propios de la economía mixta, máxime si se pone en relación con la ampliación de la intervención comunitaria en los ámbitos social y del empleo y de las formas de intervención. La sustitución de las formas de integración negativas por otras positivas, que implica la intervención comunitaria en los nuevos espacios abiertos desde Maastricht, permiten dar este salto en la argumentación.

Los principios de libre mercado y competencia y las cuatro libertades básicas pierden el carácter absoluto y su capacidad de condicionar el ordenamiento comunitario en la medida en que conviven con objetivos y medios de actuación constitucionalizados que permiten su corrección. El problema se plantea entonces en el juego de la relación contradictoria entre principios que debe ser jurisprudencialmente construidos utilizando los criterios de ponderación. En opinión de Sauter, ni siquiera los más exigentes tests de proporcionalidad, escasamente usados por la Corte, permiten desequilibrar esta nueva convi-

214 SAUTER, W., "The economic constitution...", op. cit.

215 CARONNA, F., "Qualche spunto...", op. cit.; CASSETTI, L., La cultura del mercato..., op. cit.

216 SAUTER, W., "The economic constitution ...", op. cit. 
vencia plural de criterios y principios que alejan la constitución económica europea de la economía de mercado ordoliberal ${ }^{217}$.

Por ello, concluye este autor «introduciendo el concepto de constitución económica, y conceptualizando las cuatro libertades, la competencia y los derechos económicos individuales, los ordoliberales han hecho una mayor contribución a la teoría constitucional de la Unión europea. Podemos aceptar que el Tratado contiene una constitución económica... Esta constitución económica ha cogido forma a medida que la Corte elabora principios para resolver conflictos entre derechos económicos individuales y políticas públicas en los niveles nacional y comunitario. Sin embargo, los ordoliberales han sobreinterpretado la constitución económica de la Comunidad imponiendo el liberalismo. Bajo la constitución económica de la U.E., la libertad económica no está aislada: se restringe a lo necesario para establecer el mercado interno y es objeto de excepciones de interés público en los niveles nacional y comunitario. Por ello, objetivos públicos legítimos pueden justificar excepciones de los principios del mercado como resultado de decisiones políticas.... ${ }^{218}$.

Parecería, pues, que la reflexión doctrinal sobre la evolución de la constitución económica europea el Tratado de Amterdam, en la medida en que incorpora políticas y espacios de actuación vinculadas a la cohesión social, autorizaría una nueva perspectiva de enfoque. Amsterdam podría significar el "cierre del estadio histórico previo" 219, que se justificaria por el fortalecimiento del principio de solidaridad hasta alcanzar una potencialidad de limite a la autonomía del mercado. El nuevo artículo 16 del Tratado expresaría esta nueva centralidad social que ahora ahora se instrumentaría jurídicamente con mayor vigor $^{220}$. Sin embargo la potencialidad que parecía encerrar el Tratado de Amsterdam ha sido prontamente relativizada. De tal manera que las aportaciones referidas no han deshecho la contradicción entre el "primado del objetivo económico y los principios igualitarios»221. Ciertamente las novedades más recientes de los Tratados precisan un análisis más detenido que esclarezca su alcance.

217 SAUTER, W., "The economic constitution ...", op. cit.

218 SAUTER, W., "The economic constitution ...", op. cit.

219 LOPEZ PINA, A., "Las tareas públicas en la Unión Europea», en Rev. de Derecho Comunitario Europeo, 1998, n. ${ }^{\circ}$, págs. 353-88.

220 LÓPEZ PINA, A., "Las tareas públicas en la Unión Europea», op. cit.

221 LóPEZ PINA, A., "La ciudadania, presupuesto de una República Europea (Apuntes para una política del derecho) $"$, en Civitas Europa, 2000, n. ${ }^{\circ}$ 4, págs. 7-32. 


\subsection{Mercado y ordenamiento de la Unión Europea}

El intento de recuperar una conexión con la relación entre política y economía vinculada a la tradición constitucional de los Estados miembros de la Unión se basa en una sobrevaloración de los elementos sociales que aparecen desde el Acta Única, que, en nuestra opinión, no permite afirmar el pretendido equilibrio en que se basa la tesis de la neutralidad del Ordenamiento comunitario. De hecho, los planteamientos que pretenden una hegemonía de los derechos en el nuevo proceso de constitucionalización europea son más cautos y no exentos de incertidumbres ${ }^{222}$, sin una real constitucionalización de los derechos resultaría, según Ridola, difícil alcanzar niveles profundos de integración y sería difícil la acción correctora de los desequilibrios económicos y sociales ${ }^{223}$. Otra vez se imponía la lógica de un ordenamiento prevalentemente sectorial y la vis atrayente del mercado.

Los argumentos antes presentados resultan contradichos por la propia formulación de los Tratados.

La referencia a la neutralidad de los Tratados sobre el régimen de propiedad y de iniciativa económica no puede entenderse como determinante para fundar la tesis de la neutralidad de la constitución económica por una doble razón. En primer lugar, porque la uindiferencia" del derecho originario no significa exención de las normas del mercado, sino sumisión cualquiera que sea el régimen de propiedad $^{224}$, por ello, la titularidad es un elemento irrelevante que no prejuzga ni condiciona la centralidad e irradiación del mercado como principio constitucional. En segundo, porque la posibilidad de excepcionar el mercado, en materia de servicios de interes económico general (art. 86.2 del Tratado de Amsterdam, versión armonizada) significa el sometimiento de la relación mercado-interes económico general a los términos de regla-excepción sobre la que resulta imposible articular el condicionamiento del mercado.

La aparición de objetivos sociales en los Tratados resulta notablemente insuficiente para equilibrar el peso del principio del merca-

222 RIDOLA, P., "Diritti di libertà e mercato nella "Costituzione europea" ", en La Costituzione europea, Cedam, Padua, 2000, págs. 323-57. También Agostina CABIDDU, M., "Costituzione europea e Carta dei diritti fondamentali", en Profili della costituzione economica europea, II Mulino, Bolonia, 2001, págs. 177-208.

223 RIDOLA, P., "Diritti di libertà...", op. cit.

224 Caronna, F., "Qualche spunto...", op. cit. 
do. Los objetivos sociales, genéricamente formulados en el art. 2 resultan introducidos en un contexto de compatibilidad con finalidades que comprometen su status en el ordenamiento. Igualmente, los instrumentos de actuación (art. 3) suponen una subordinación de los objetivos sociales que recupera la relación establecida entre bienestar social y mercado en el Tratado de Roma. El artículo 4 supone confinar a los objetivos sociales al nuevo papel de legitimación formal.

La contradicción que establece Luciani entre Derechos sociales y Ordenamiento comunitario es difícilmente objetable ${ }^{225}$. Los Derechos sociales no existen en los tratados, el vinculo jurídico de la apelación a los instrumentos internacionales o al derecho blando en la materia es inexistente $y$, en todo caso, se proclama la sumisión de la influencia de éstos a las exigencias del mantenimiento de la competitividad, en un ambiente que parte del paradigma de la contradicción entre ambos términos. Ni Amsterdam, ni Niza superan los obstáculos que el propio ordenamiento impone a la lógica social.

La cohesión como espacio de la política, no de los derechos, resulta incapaz, en la dinámica europea, de actuar como límite al mercado226.

Posiblemente, el ejemplo más evidente, por emblemático, de la subalternidad de los objetivos sociales sea la política de empleo, estreIla de las innovaciones sociales de Amsterdam, que debía traducir, en parte, las nuevas orientaciones del art. 2. Los objetivos en materia de empleo son potenciar una mano de obra cualificada, formada y adaptable y conseguir mercados laborales con capacidad de respuesta al cambio tecnológico. Se sustituye el Derecho al trabajo, en su formulación conformada doctrinal y jurisprudencialmente en el constitucionalismo social, por la "empleabilidad"227, concepto que introduce un nuevo principio en el ordenamiento, la flexibilidad, capaz de redefinir el Derecho del trabajo del Estado social. Empleabilidad es, posiblemente, la antítesis del Derecho al trabajo, obviamente inexistente ${ }^{228}$.

225 LUCIANI, M., "Diritti sociali e integrazione europea", en La costituzione europea, op. cit., págs. 507-54.

226 TESAURO, F., "La politica di coesione ed il rapporto con le altre politiche communitarie: filosofia neoliberista o interventista nella costituzione economica comunitaria", en Fondi strutturali e coesione..., op. cit., págs. 123-34.

227 CAMPIGLIO, L., y TIMPARO, F., "La dimensione economica della coesione sociale: lavoro, famiglia e Welfare state", en Profili della costituzione econmica europea, op. cit., págs. 395-430; GómEZ JENE, M., "La política de empleo comunitaria" (Cap X), en Políticas Comunitarias, Ed. Colex, Madrid, 2001, págs. 379-88.

228 LUCIANI, M., "Diritti sociali e integrazione europea», op. cit. 
Dos últimas consideraciones respecto a los argumentos esgrimidos por los sostenedores de la tesis de la neutralidad de la constitución económica comunitaria permiten limitar el alcance de esta propuesta. En primer lugar, el único instrumento técnico que permite introducir lógicas distintas al mercado, aun colocadas en situación de excepcionalidad, es el del servicio público. En contra de la propuesta interpretativa que la doctrina referida ha realizado, podemos decir que la actuación comunitaria y su ordenamiento han actuado como un elemento de reducción y funcionalización al mercado de esta categoria iuspublicista ${ }^{229}$. El eje entorno al cual ha girado la interpretación del Tratado de Amsterdam como constitucionalización de una nueva reordenación de la relación mercado y política ha sido el nuevo artículo 16. En este precepto se ha querido ver la traducción, en forma de principio, de la nueva definición de los fines de la Comunidad recogidos en art. 2 y del equilibrio entre objetivos económicos y sociales.

Veamos, pues, qué virtualidad puede otorgarse a este precepto y si introduce elementos de ruptura frente a las formulaciones contenidas en el antiguo artículo 90 (ahora 86 ).

Ciertamente la génesis del artículo 16 parece poder interpretarse como un intento de insertar la lógica de los servicios públicos en el Ordenamiento comunitario ${ }^{230}$, aunque el resultado final diste mucho de las pretensiones francesas. Sin embargo, considerando la solución dada, el artículo 16 es un compromiso que no supone la recuperación de la autonomía de los Estados en la definición de los servicios públicos y mantiene la centralidad del artículo 86.

Con independencia de su génesis y antes de valorar el alcance de este precepto en orden a legitimar la intervención pública contrastante con el mercado, conviene hacer algunas precisiones respecto al tratamiento comunitario de los servicios públicos. Como es conocido, la noción de servicio público es ajena el Derecho comunitario que, salvo la referencia periférica realizada a las ayudas estatales en materia de trasportes (art. 73), no está presente en los Tratados. La alusión a

229 AMIRANTE, C., Unione sopranazionale e riorganizzazione costituzionale dello stato, Giappichelli, Turín, 2001, págs. 23-55.

230 Ross, M., "Article 16 EC, and service of general interest: from derogation to obligation?", en European Law Review, febrero 2000, págs. 22-38; RODRIGUES, S., "Les services publics et le Traité d'Amterdam. Genèse et portée juridique du projet de nouvel article 16 du Traité CE», en Rev du Marchè Commun et de L'Union Europèenne, $1998, \mathrm{n} .^{\circ} 414$, págs. 37-46. 
los "servicios económicos de interés general», por su significado y origen, no resulta equiparable ${ }^{231}$.

El papel inicial que los tratados reservan a los uservicios de interés general" (art.86) es el de establecer un espacio de excepcionalidad respecto al mercado, pero reconducido a la posibilidad de actuación de los estados en su ámbito territorial y dentro de estas notas económicas ${ }^{232}$. El Tratamiento que de esta categoría realizan los tratados no tiene por objeto establecer, fuera de la acción estatal, un principio de relación público-privado distinto del mercado, como confirma el propio artículo 86.1. Sólo desde el punto de vista formal, el nuevo artículo 16 supone una innovación.

En la reconstrucción del significado del artículo 86, hasta la aparición del 16, deben aceptarse, fruto, tanto de la construcción doctrinal, como jurisprudencial, las afirmaciones siguientes:

a) El artículo 86.2 se coloca en una posición de excepción respecto a la regla que se formula en el párrafo $10^{\circ}$ del mismo precepto $^{233}$. Ésta introduce la obligación a los Estados miembros de crear mercados concurrenciales en los ámbitos antes organizados mediante servicios públicos que excluían las normas concurrenciales ${ }^{234}$. Es precisamente esta norma la que priva de virtualidad a lo dispuesto en el artículo 295; la neutralidad en el régimen de propiedad carece de importancia si se impone la sumisión a las normas de la concurrencia.

El artículo 86.2 , en conexión con el párrafo $3 .^{\circ}$ impone la obligación de demostrar la inidoneidad del mercado para la satisfacción de la misión específica encomendada a las empresas que prestan esos servicios.

231 SORACE, D., "Servici pubblici e servici (economici) di pubblica utilità", en Diritto pubblico, 1999, págs. 371-425.

232 PINOTTI, C., Gli aiuti di stato alle imprese nel diritto comunitario dell concorrenza, Cedam, Padua, 2000, págs. 101-4.

233 CoRso, G., "l servizi pubblici nel diritto comunitario", en Rivista giuridica quadrimestrale dei pubblici servizi, 1999, n.0 1, págs. 7-19; SALVIA, F., "ll servizio pubblico: una particolare conformazione dell'impresan, en Diritto pubblico, 2000, n. ${ }^{\circ} 2$, págs. 535-53.

234 MunARI, F., "Imprese "pubbliche" e servizi di interesse generale», en II diritto privato dellUnione Europea, tomo II, Giappichelli, Turín, 2000, págs. 1251-67. 
La prueba de inidoneidad impuesta por la intervención prevista de la Comisión que controla el cumplimiento del artículo 86 y sus previsiones ${ }^{235}$, impone una lógica subsidiaria al control público de los servicios de interés económico en relación con las misiones específicas de éstas. Subsidiariedad que recuerda a la relación construida en el liberalismo entre servicios públicos emergentes y mercado ${ }^{236}$. La relación regla-excepción que instaura este precepto respecto al mercado y al control público de determinadas actuaciones económicas destruye la pretendida neutralidad comunitaria de la constitución económica, restableciendo la primacia de la íniciativa privada ${ }^{237}$.

b) La subsidiariedad económica del control público de los servicios y de la sustracción a las normas de la competencia, articuladas técnicamente a través de la intervención de la comisión y del TJCE mediante la aplicación del test de proporcionalidad, altera profundamente la noción de servicio público, genéricamente difundida en los ordenamientos estatales. La intervención comunitaria ha propiciado la introducción del conflicto en la misma noción de servicio público y la expansividad del mercado en las áreas de intervención ajenas a la noción de servício de interés económico. Dentro de los servicios no económicos, la vis expansiva del mercado permite detectar espacios mercantilizables (caso Höfner). El tipo de argumentación de la Corte, según algún autor ${ }^{238}$, favorece esta desnaturalización del servicio público. Con independencia de la calificación de las actividades realizadas por el Estado, desde la perspectiva comunitaria se valora como actividad económica y si es susceptible de ser así considerada (actividad económica de gestión empresarial) se impone la lógica concurrencial ${ }^{239}$.

235 Conso, G., "l servizi pubblici nel diritto comunitario", op. cit.; PINOTT, C., Gli aiuti di stato alle imprese nel diritto comunitario dell concorrenza, op. cit., págs. 94-108.

236 SALVIA, F., "ll servizio pubblico: una particolare conformazione dell'impresan, op. cit.

cit.

237 MUNARI, F., "Imprese "pubbliche" e servizi di interesse generale», op.

238 SALVIA, F., "ll servizio pubblico: una particolare conformazione dell'impresan, op. cit.

239 SALVIA, F., "ll servizio pubblico: una particolare conformazione dell'impresa», op. cit. 
Por otra parte, en la consideración de la Comisión ${ }^{240}$ el servicio económico de interés general acaba confundiéndose con la noción de servicio universal operando una reducción de la noción de servicio público. El núcleo fuerte se traslada al servicio universal y en torno a éste, se construye la posibilidad de articular la excepción de las normas sobre la competencia ${ }^{241}$. Resulta necesario recordar, a estos efectos, que servicio universal no es lo mismo que servicio público ${ }^{242}$. Por su alcance y significación, el servicio universal resulta funcional a la preservación de la norma del artículo 86.1.

c) Las nociones de servicio público, ligada a la consolidación del Estado social, y servicio universal, como manifestación nuclear de la misión específica a realizar por los servicios de interés económico general, representan conceptos opuestos en su significación. No parece forzado, como ha hecho la doctrina más autorizada ${ }^{243}$ vincular a la idea de intervención pública y gobierno político de la economía, la noción de servicio público, que constituiría un instrumento privilegiado de intervención cuyo objetivo sería el de condicionar el mercado. Por el contrario, la idea de servicio universal expresa una propuesta diferente, representa la reclusión de este núcleo en el ámbito de la legitimación residual del proceso de extensión del mercado a los instrumentos de gobierno económi$\mathrm{CO}^{244}$. Todo lo más puede considerarse «el servicio universal, en cierto modo el resultado de un compromiso entre la exigencia de salvaguardar estos valores comunes y la de potenciar la eficiencia y el desarrollo de los sectores considerados a través de la liberalización del acceso a las empresas interesadas, de forma que favorezca la competencia económica entre ellos $y$, en consecuencia, la formación de un verdadero y propio «mercado» ${ }^{245}$.

Si la consideración en los Tratados del interés general resulta subordinada al mercado, como espacio en el que se alcanza la satis-

240 Véase Comunicación de la Comisión sobre los servícios de interés general de septiembre de 1996.

241 CORSO, G., "l servizi pubblici nel diritto comunitario", op. cit.

242 GasparinI CASARI, V., "ll servizio universale", en I/ diritto dell'economia, 2000, n. ${ }^{\circ} 2$, págs. 263-89.

243 Pототschnig, U., Servizi pubblici, Cedam, Padua, 1964.

244 SALVIA, F., "ll servizio pubblico: una particolare conformazione dell'impresa", op. cit:; GASPARINI CASARI, V., "ll servizio universale", op. cit.

245 GaSPARINI CASARI, V., "ll servizio universale", op. cit. 
facción de éste, queda por ver si el artículo 16 introducido en Amsterdam incluye potencialidades distintas de la relación anteriormente establecida entre público y privado.

La referencia primaria debe ser tanto al texto del precepto, como al derecho complementario gestado en torno a la introducción de este precepto en la reforma del Tratado de Roma. Ciertamente, la doctrina ha reparado en la formulación literal del artículo 16, que obliga (incluso en las lecturas más optimistas) a una relativización de su alcance ${ }^{246}$. Las alusiones al papel de los servicios de interés económico general con relación a la cohesión social no pueden obviar la confirmación del cuadro jurídico que disciplina la relación entre normas de la competencia y los servicios contemplados en este precepto. La referencia a los artículos 73, 86 y 87 resulta determinante para contener el potencial innovador del artículo 16. Por otra parte, la referencia a la acción comunitaria tendente a velar por el cumplimiento de los cometidos asignados a estos servicios no supone una novedad con respecto al artículo 86.2 y a la salvaguarda del cumplimiento de la misión específica confiada a los servicios económicos de interés general. El artículo 16 supone normativamente una confirmación del estatuto jurídico anterior de estos servicios.

Por otra parte, las disposiciones interpretativas incorporadas al tratado de Amsterdam no hacen sino confirmar estas consideraciones. En efecto, la declaración sobre el artículo 16, con su apelación a la jurisprudencia del Tribunal de Justicia, no hace sino fijar el estado de la cuestión en el punto de llegada que hemos comentado. La relación público-privada o, si se quiere, mercado-gobierno político jurisprudencialmente construida no ha hecho posible corregir la centralidad cuasi absoluta del mercado.

Ni siquiera el protocolo 32 sobre el sistema de radio-difusión pública, en directa relación con la consideración de servicio público de este sector, permite otorgar más virtualidades que las ya exploradas al artículo 16, esa es, al menos, la opinión doctrinal. "Parece, así pues, que el protocolo adjunto al Tratado de Amsterdam no innova, en lo que se refiere al servicio público de radiodifusión, respecto a la tradicional interpretación del artículo 90.2 del Tratado de la CEE» ${ }^{247}$.

246 Ross, M., "Article $16 \mathrm{EC}$, and service of general interest: from derogation to obligation?", op. cit.; SORACE, D., "Servici pubblici e servici (economici) di pubblica utilità", op. cit.

247 PINOTTI, C., Gli aiuti di stato alle imprese nel diritto comunitario dell concorrenza, pág. 114. 
En la medida en que los mecanismos de control comunitario de la excepción de las normas de la competencia permanecen intactos, y que la intervención de la Comisión ha sido relevante en la introducción de las novedades más trascendentes en materia de servicios públicos (Comunicación de la Comisión de septiembre de 1996), parece conveniente aludir a la Comunicación de la Comisión sobre "los servicios de interés general en Europa" de 20 de serptiembre de 2000, que se realiza sobre el nuevo marco jurídico.

La Comunicación de septiembre de 2000 toma como punto de partida el nuevo artículo 16 y revalida su conexión con la cohesión social para pasar a situar el juego de los servicios en la sumisión a la lógica del mercado. Pero lo que importa es la fijación de los principios que la Comisión hace.

En primer lugar, reitera la primacía del mercado y sus normas frente a las que coloca en posición de excepción a los servicios púlbicos. Las obligaciones de interés general sólo permitirían excepcionar las normas de mercado.

«En determinadas circunstancias, especialmente cuando las fuerzas del mercado no bastan por sí solas para prestar los servicios de forma satisfactoria, las autoridades públicas podrán encomendar a determinados operadores de servicios unas obligaciones de interés general concediéndoles, en caso necesario, derechos especiales o exclusivos y/o concibiendo un mecanismo de financiación para la prestación de los servicios en cuestión" (Comunicación de la Comisión de 20-9-2002).

Esta afirmación coloca a los servicios públicos, a pesar de la reiteración del principio de neutralidad respecto a la propiedad pública o privada de las empresas, en una relación de subsidiariedad respecto al mercado, manteniendo la relación público-privado que había definido su constitución económica.

En segundo lugar, mantiene el sistema de intervención comunitaria, basado en el artículo 86.3, construido en torno a la proporcionalidad "en virtud de la cual, las restricciones de la competencia y las limitaciones de las libertades del mercado único no exceden lo necesario para garantizar el cumplimiento eficaz de la misión" (Comunicación de la Comisión), vinculando el sistema del artículo 86 al 16 , del que resulta su instrumentación. Así, el párrafo $2 .^{\circ}$ del artículo 86 es considerado el punto de equilibrio entre mercado y servicio universal y la proporcionalidad es definida en los términos tradicionales. 
Tercero, en la valoración de la experiencia de la liberalización de mercados realizada por la Comisión se reafirma el principio acuñado en el tratado de Roma de 1957 respecto a la relación entre mercado e interés social, que ha permitido mantener la subalternidad de este último. El mercado era el ámbito de satisfacción de las necesidades sociales en cuya dinámica de funcionamiento deberían resolverse. "La liberalización de los servicios conforme el programa del mercado único parece haber tenido un impacto positivo en la disponibilidad, calidad $y$ asequilibilidad de los servicios de interés general. Sin embargo; esto no significa necesariamente que tales servicios estén funcionando de forma satisfactoria... Como consecuencia, aún están por cosechar los beneficios completos de la liberalización para todos los grupos sociales... El objetivo común es beneficiar a los ciudadanos de Europa a través del desarrollo de un mercado único competitivo" (Comunicado de la Comisión).

Parece pues que el artículo 16 se agota en sí mismo y resulta difícil derivar de este precepto un principio favorable a la intervención pública en confrontación con el mercado que permita operar, más allá de la excepción de los servicios públicos estatales a las normas del mercado, en un escenario de servicios europeos.

De esta forma, la noción de servicio universal, categoria distinta y sustitutiva de la del servicio público es coadyuvante al proceso de liberalización de los sectores antes vinculados a este instituto y cumple funciones de garantía del funcionamiento del mercado distante de la lógica del Estado social. Esta categoría introduce un nexo de unión con el paradigma del Estado regulador, configurándose como elemento de heterocorrección del mercado, funcional a su existencia ${ }^{248}$.

La vinculación del ordenamiento comunitario y su constitución económica al Estado regulador, aparece con claridad en la constitucionalización de los principios que legitiman la ordenación del Sistema Monetario Europeo, sobre la base del Banco Central Europeo, expresión del paradigma regulador.

Predieri ha calificado a la estabilidad, principio recogido en el artículo 4, como valor constitucional capaz de irradiar a todo el ordenamiento y condicionar el conjunto de las políticas comunitarias "La estabilidad si no constituye un derecho subjetivo en el micro derecho... opera como base al nivel de macroderecho y constituye proyecto, indi- 
rizzo constitucionalmente consolidado por un órgano constitucional inserto en el plan... La decisión de estabilidad es una decisión del metaestadon 249 .

Mostrada la dificultad de afirmar la neutralidad de constitución económica europea, en base a los elementos sociales introducidos en la reforma de los Tratados, nuestra propuesta es definir la constitución económica en torno a la fórmula de la "economía social de mercado". El Ordenamiento comunitario recupera y constitucionaliza las formulaciones de la Escuela de Friburgo, que, por otra parte, estan en la base del paradigma del Estado regulador.

De esta forma, «economía social de mercado» en el ordenamiento comunitario significa: centralidad del mercado, reconocimiento de su autonomia, tutela pública de sus reglas, es decir, defensa de la concurrencia ${ }^{250}$. Esta propuesta no excluye la intervención pública de coyuntura, ni cierto grado de intervención social, de caracter subalterno, pero sin comprometer la centralidad del mercado como principio fundamental articulador del sistema.

Constitución económica, de esta forma definida, significa tambien inversión de la relación política-economía y subalternidad de la primera, es decir, ruptura del vínculo social que caracteriaba la constitución económica del Estado social.

En otras palabras, la constitución económica europea supone el asentamiento de una nueva constitución material del Estado postsocial251.

249 Predierl, A., "L'Unione economica monetaria", en La Costituzione europea, Cedam, Padua, 2000, págs. 119-146.

250 NinATTI, S., "Interventi pubblici nell'economia tra mercato unico e principio de subsidiarietà. Orientamenti della giurisprudenza comunitaria e della dottrina tedesca", en Riv. Ital. Dir. Pubblico cominitario, 1996, págs. 311-27.

251 BILANCIA, F., "Brevi note su costituzione materiale...", op. cit. 